Article

\title{
Techno-Economic Mapping for the Improvement of Shallow Geothermal Management in Southern Switzerland
}

\author{
Rodolfo Perego ${ }^{1, *(D)}$, Sebastian Pera ${ }^{1}$ and Antonio Galgaro ${ }^{2}$ (D) \\ 1 Institute of Earth Sciences, University of Applied Sciences and Arts of Southern Switzerland SUPSI, \\ Campus Trevano, CH-6952 Canobbio, Switzerland; sebastian.pera@supsi.ch \\ 2 Department of Geosciences, University of Padova, Via Gradenigo, 6, 35131 Padova, Italy; \\ antonio.galgaro@unipd.it \\ * Correspondence: rodolfo.perego@supsi.ch; Tel.: +41-58-666-62-18
}

Received: 13 December 2018; Accepted: 11 January 2019; Published: 16 January 2019

\begin{abstract}
Cantone Ticino, a mountainous region located in the southern part of Switzerland, is greatly affected by the continuous growth of subsurface exploitation through the use of both closed-loop and open-loop geothermal systems. In this study, techno-economic maps for shallow geothermal potential of Cantone Ticino are produced, considering closed-loop systems. The work starts with the identification of the main parameters affecting the techno-economic potential such as GST and thermal conductivity. Maps for different indicators of techno-economic feasibility are created and compared against real data/measurements. An empirical method is tailored to derive a map of the techno-economic geothermal potential, expressed as meters required to provide $1 \mathrm{~kW}$ of installed power. The produced map shows an overall discrepancy from real installed length data of approximately $\pm 23 \%$. Moreover, compared with current regulation, the produced maps show an unoptimized management of the shallow geothermal resource, since high potential zones are commonly located where the installation of BHE is not permitted and often closed-loop systems are installed where the estimated potential is lower, mainly in alluvial fans. In light of these considerations, the authorization process in Cantone Ticino for BHE should be revised taking into account the real techno-economic potential.
\end{abstract}

Keywords: Ground Source Heat Pumps (GSHP); mapping; potential; Switzerland; payback period; shallow geothermal

\section{Introduction}

Low enthalpy geothermal energy is a renewable energy that is becoming widely exploited within Europe, especially through the use of closed-loop systems. These systems exchange heat with the subsurface by means of a thermo-vector fluid, which circulates in a plastic pipe installed in the subsurface. It is a safe technology which proved to be very efficient and economically advantageous during the years given a proper design and installation. This technology is relatively mature but it is not cheap, since the installation costs are the main constraints that reduce its deployment throughout the entire Europe and economic benefits are noticed after years of operation.

Switzerland is one of the most advanced countries from the low-enthalpy geothermal energy standpoint. The state-of-the-art drilling techniques, the favorable geological and thermal conditions, the consistent know-how owned by the sector experts make this technology one of the most popular between all the available renewable energies, with the highest spatial density of probes in the world [1].

According to the Swiss Federal Office of Energy [2] a large-scale use of geothermal heat pumps could allow obtaining a relevant reduction of $\mathrm{CO}_{2}$ emissions and fossil fuels consumption. Geothermal 
heat pumps are usually implemented in new buildings, especially public ones that adopt the Swiss certification MINERGIE ${ }^{\circledR}$ [3], but this technology could also be used to satisfy energy demand in historical or cultural buildings.

Low enthalpy geothermal technology has already been well-deployed in Cantone Ticino, which is a region located in southern Switzerland, delimited to the North by Gotthard Massif and surrounded by Italy to its West (Cantone Vallese, Lombardy and Piedmont), South (Lombardy) and East (Lombardy and Cantone Grigioni) (Figure 1).

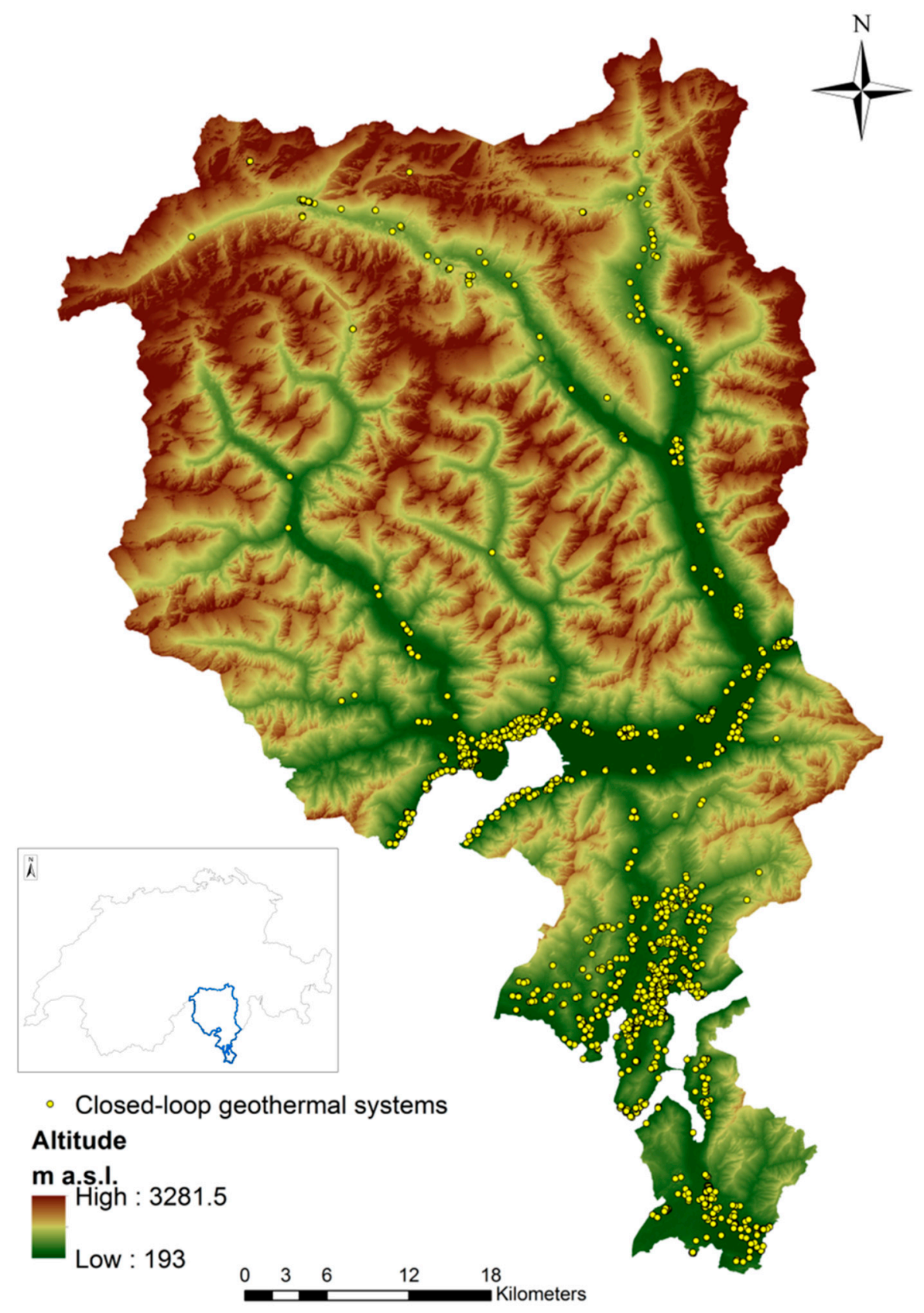

Figure 1. Location of the study area, with highlighted the distribution of closed-loop borehole heat exchanger (BHE) heat exchangers.

The last two decades (approximately from 1997 to 2017) have led to the current massive subsurface thermal exploitation by means of both closed-loop and open-loop geothermal systems. As a consequence, the region currently hosts a large number of geothermal installations, with an overall 
density of approximately 1.5 probes $/ \mathrm{km}^{2}$. Considering only main aquifers, where the majority of population lives, this density increases to 16 probes $/ \mathrm{km}^{2}$. Considering main cities, the value rises to 44 probes $/ \mathrm{km}^{2}$. This large amount of installations subsequently arise issues regarding short mutual distances or adjoining probe fields that will influence ground temperatures and system performances in the long term [4]. Shallow geothermal energy development in Cantone Ticino will be increasingly important, since at least $20 \%$ of energy requirements for new buildings will have to be provided from renewable energies as stated in [5]. Currently Cantone Ticino uses $28.9 \%$ of produced energy for building conditioning [6]. According to 2016 data, the annual energy demand for residential buildings is $3.398 \mathrm{GWh}$, equivalent to $35.6 \%$ of Cantonal consumption. Approximately $80 \%$ of this energy is used for building conditioning (2760 GWh in 2016) and $20 \%$ for electrical devices and lighting. The main energy source used for heating is heating oil (55.5\%). The other sources are: natural gas $(18 \%)$, electricity $(11.9 \%)$, wood $(7.6 \%)$ and, combined, solar thermal, heat pumps and heat from waste (7\%). As a rough estimation, $\mathrm{CO}_{2}$ emissions produced by residential buildings in Cantone Ticino are quantified in 562,000 $\mathrm{tCO}_{2}$ /year, of which 449,600 $\mathrm{tCO}_{2}$ /year are emitted from heating.

\subsection{Closed-Loop Systems in Cantone Ticino Diffusion And Licensing Process}

In 1997, less than 10 probes were installed and registered, according with [7], while by 2005 this number had grown to more than 2000. During the last 12 years, from 2004 to 2016, requests for new geothermal system permits (both closed and open, small to large systems) went from 30 per year to more than 100 per year, with peaks of 140 per year in 2011 and 2012. Currently new requests for thermal use of the underground are a regular occurrence: the information is therefore stored in a specific database. The SUPSI- Institute of Earth Sciences (IST)'s geodatabase GESPOS (Surveys, Wells and Springs Management) [8] hosts more than 4300 georeferenced and indexed closed-loop geothermal probes distributed in more than 1100 installations. For each installation a series of administrative and technical information is collected. Data analysis allows estimating an overall closed-loop installed power of approximately $30 \mathrm{MW}$ and an aggregate installed borehole length of approximately $550 \mathrm{~km}$, proving a strong deployment of this technology.

The majority of GSHP systems are located within Quaternary deposits (43\%) filling glacial valleys, which constitute the main background for human activities and energy exploitation. A consistent amount of probes is also installed in gneiss $(33 \%)$, granite $(10 \%)$, limestone and green schist $(6 \%)$. Figure 2a shows the frequency of each system type classified for its size: the most frequent types of installations are constituted of one and two probes (respectively $27.6 \%$ and $30 \%$ of the total). Systems constituted by more than 10 probes represent only $7.5 \%$ of the total, but they account for $35 \%$ of the overall number of probes.

Figure $2 \mathrm{~b}$ presents the average total power per number of probes in the system. The weighted mean heating capacity observed in Cantone Ticino is approximately $25 \mathrm{~kW}$. A power regression between installation power below $100 \mathrm{~kW}$ and probes number was found $\left(\mathrm{R}^{2}=0.956\right)$ : according to this regression, for a mean heating capacity of $25 \mathrm{~kW}$ a representative system was constituted of four probes. This scenario was considered as referential for further simulations presented in this paper.

The authorization process of closed-loop systems is based on restrictions arising from the enforcement of the Swiss water protection act and ordinance [9] and contained in [10]: an excerpt of this regulation is shown in Table 1. It states that new closed-loop systems cannot be installed within S1 and S2 wellhead protection zones and as a rule they are not allowed even in S3, except for specific situations. They are always allowed in üB ("übriger Bereich") remaining territory where there is no occurrence of exploitable groundwater. Within the Au (exploitable groundwater) sector, generally geothermal probes are not allowed except for "sacrifice areas" where the presence of conflicts precludes groundwater exploitation for drinking purposes [11]. In these areas the great presence of conflicts (sewers, industries etc.) precludes a creation of groundwater protection areas in compliance with the regulation: any thermal use of the underground is therefore admitted. 

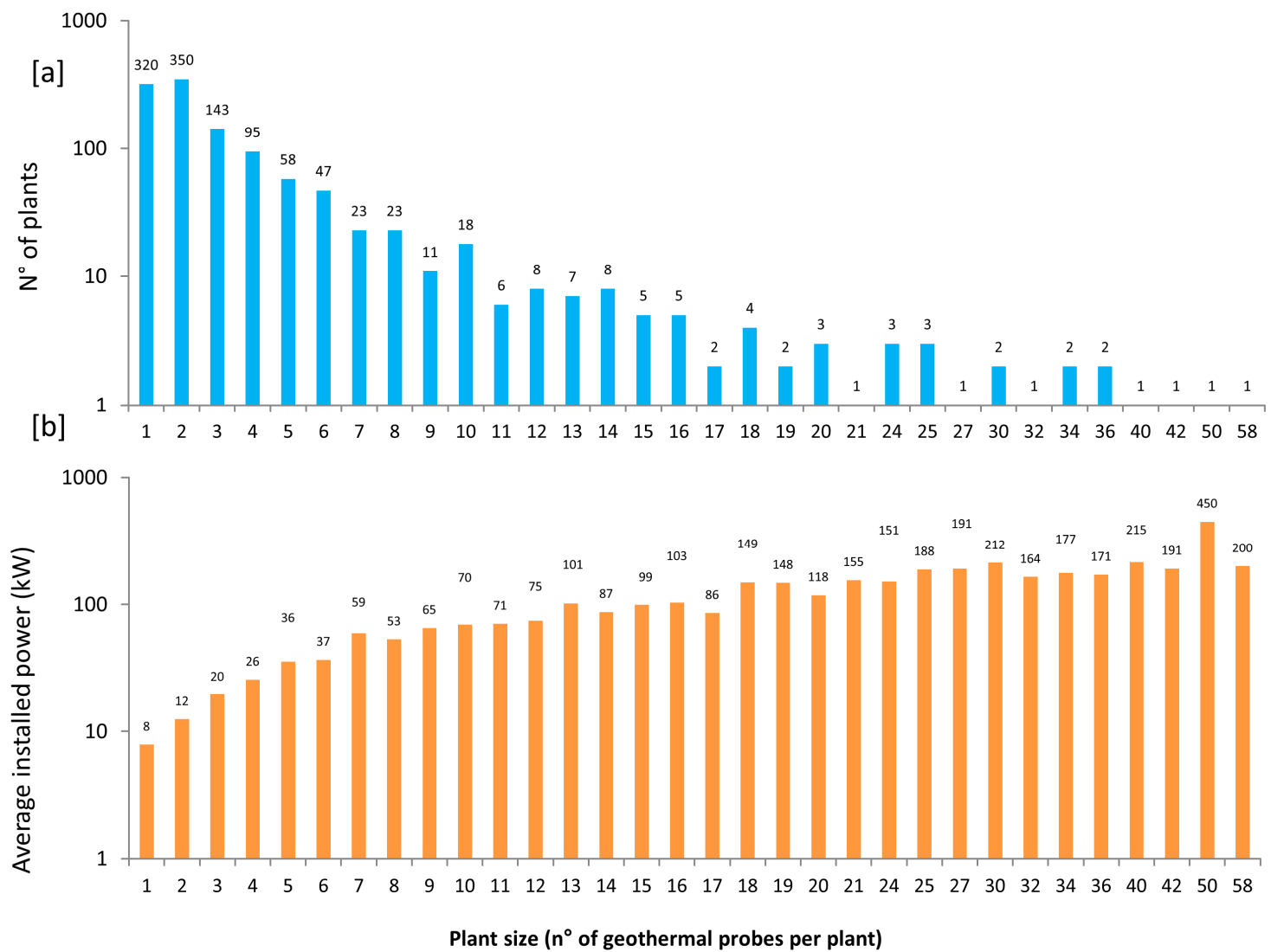

Figure 2. Basic statistics for Cantone Ticino geothermal systems: (a) amount of systems per size class; (b) average installed power per size class.

Table 1. Reference table for the exploitation of heat from ground and subsurface in Switzerland.

\begin{tabular}{|c|c|c|c|c|c|c|c|}
\hline Type of System & $\ddot{\mathbf{u B}}$ & $\mathrm{Au}$ & $\mathbf{Z u}$ & Area & S3 & S2 & S1 \\
\hline Geothermal probes (vertical systems) & + & $\mathrm{b}$ & & - & - & - & - \\
\hline Underground circuits (horizontal systems) & + & $+_{4}$ & & $-2 / 4$ & $-{ }_{b / 5 / 4 / 7}$ & - & - \\
\hline Geothermal piles and other thermo-active elements & + & $\mathrm{b}$ & & $-2 / 4$ & $-{ }_{b}$ & - & - \\
\hline Wells for groundwater withdrawal, for heating and cooling & + & $\mathrm{b}$ & & - & - & - & - \\
\hline Coaxial wells & -6 & -6 & & - & - & - & - \\
\hline
\end{tabular}

(+) No restrictions; (b) admitted or not after a case by case analysis by the Authority, requires authorization; (-) forbidden; (-b) forbidden but could be waived if it is a particular case; (2) can be authorized if a detailed hydrogeological report identifies the future limits of the S3 protection zones; (4) the installations must be realized at least $2 \mathrm{~m}$ above the maximum piezometric head level; (5) no direct-expansion heat pump; (7) if circuits are located in the soil (horizons A or B) and not in the sub-soil, an authorization can be granted; (6) authorized only if specific geophysics and hydrogeological studies state that there is no threat for groundwater.

A case-by-case analysis of environmental impact assessment for every GSHP system can be a difficult, time-consuming and expensive task, so a detailed and verified map of the techno-economic potential can be useful. Cantone Ticino adopts a "rule of thumb" to prevent potential interferences among neighboring installations: new systems must be installed at a distance of at least $5 \mathrm{~m}$ from the edges of the parcel they are installed in. In this way adjacent parcels should have two neighboring geothermal systems which are at least at $10 \mathrm{~m}$ distance, ideally preventing from potential thermal interferences. The estimation of the suitability for closed-loop GSHPs and its mapping is important from an economic and decisional standpoint, since it could give precious advices on how to regulate its deployment and could allow a better management of thermal resource. The aim of this paper is to give some indications to improve the current authorization procedure of GSHP systems, by adopting 
more dynamic and physically robust methods which also account for the extractable potential. This approach would better balance environmental, technological and legal aspects on a spatial basis. This procedure is achievable by using Geographic Information Systems (GIS), which are powerful tools that can manage numerous and large spatial data, performing computationally demanding calculations. The aim was to obtain quality products with high spatial resolution even for large territories.

\subsection{Low Enthalpy Geothermal Potential Mapping in Literature}

The scheme proposed by the United States National Renewable Energy Laboratory (NREL) [12], summarizes a clear concept of "potential" referred to a renewable energy. The technical potential of a renewable energy is stated as the "achievable energy generation of a particular technology given different constraints". At the base of the pyramid there is the physical theoretical energy extractable or generated by the renewable source, which is always limited by the technological means and by the expertise. In particular, for shallow geothermal systems, the extractable energy is limited by the COP/EER of the heat pump, by probe material and grouting. Technical potential is limited by economic potential, since a high-performance technology could be economically disadvantageous due to high fuel consumption, high material production costs or high labor costs. The top of the pyramid is represented by market constraints, which commonly represent policy implementation, regulatory restrictions, competition with other technologies, investor response and the attractiveness of the resource perceived by stakeholders. In particular, this last aspect has become more and more important in the last years to promote renewable energy solutions.

In the past decades few research papers focused on the estimation of shallow geothermal potential, especially through mapping procedure. Only recently this topic has gained visibility, clearly proving that the spatial management of shallow geothermal systems (both open and closed) is becoming more relevant at local or regional scale.

A shortlist of papers focusing on this topic could begin with the work from [13], which gives suggestions on the parameters to consider for the assessment of the potential, such as the percentage of heat demand that could be satisfied by geothermal systems, maximum allowable drilling depth and potential reduction of $\mathrm{CO}_{2}$ emissions.

The work from Garcia-Gil et al. [14] uses analytical formulas to calculate the Low Temperature Geothermal Potential (LTGP) for both open and closed systems. The mapping work from Bertermann et al. [15] estimates the Very Shallow Geothermal Potential (vSGP) for horizontal systems. A great amount of data coming from different scientific areas had to be homogenized and implemented into an online GIS. The work from Gemelli et al. [16] proposes a methodology to map economic factors affecting GSHP systems such as energy cost, payback time, $€ / \mathrm{kg}, \mathrm{CO}_{2}$.

The work from Casasso et al. [17] estimates both open-loop and closed-loop potential for the Province of Cuneo (Italy), calculating the amount of extractable energy from the underground, by means of a specifically tailored analytical equation. The work from Arola et al. [18] estimates the open-loop potential of Finnish aquifers based on both physical properties of aquifers and the efficiency of heat pumps. The paper from Viesi et al. [19] proposes a comprehensive work that is aimed at deriving the geo-exchange potential in the Adige Valley (Italy), by using a large amount of collected data, including hydrogeological, climate and lithostratigraphic information.

Detailed work at small-scale by Galgaro et al. [20] estimates the geo-exchange potential through a comprehensive characterization of the subsurface and of the energy request from a reference residential unit.

In this paper the required BHE length that could satisfy an assigned energy requirement was considered to be the minimum index that could better describe both natural and technological constraints. From this indicator it was also possible to estimate the capital cost of the GSHP installation, which in turn allows producing economical and market index maps. The modeling part of this paper is inspired by the work from Galgaro et al. [20], especially the use of EED software [21] and the empirical relations between $3 \mathrm{D}$ parameters. 
The work procedure followed both an empirical and a regulatory/standard approach: in particular, some formulas used to evaluate temperature values (e.g., ground temperature) and energy demand parameters (e.g., the annual heating demand index) are taken from Swiss regulations/ standards, such as SIA 384/6 [22] and MINERGIE ${ }^{\circledR}$, in order to have reference values that could be consistent for Switzerland. Also most of thermal conductivity values are taken from SIA 348/6 regulation, since few in-situ thermal measurements were available. The presented work forms part of the HORIZON2020 "Cheap-GSHPs" project, which aims at reducing the installation costs of closed-loop shallow geothermal systems. The work performed by SUPSI (partner of the consortium) on Cantone Ticino was useful to test at European level a mapping procedure to estimate the techno-economic potential (for the description of the received funding see "Funding" section).

\section{Natural Resource}

The mapping procedure started with the identification of the main resource parameters affecting vertical closed-loop GSHPs operation, efficiency and dimensioning. For the considered study area, the investigated natural parameters were mean annual air temperature (MAAT) of the location, that affects ground surface temperature (GST), and thermal conductivity of the subsurface. Thermal conductivity was calculated separately for both outcrops and unconsolidated material, since they require completely different methodologies.

\subsection{Mean Annual Air Temperature (MAAT) and Ground Surface Temperature (GST) Mapping}

The initial part of the work involved the creation of a Mean Annual Air Temperature (MAAT) map for Cantone Ticino that could allow estimating Ground Surface Temperature (GST), a required input for EED software. In fact GST is used by the software to calculate ground temperature at half of the borehole length, using both thermal conductivity and heat flux information. 30 years climatic normal of GST direct measurements were not available for Cantone Ticino nor for Switzerland. A robust and homogeneous air temperature database was retrieved from the MeteoSwiss [23]. MeteoSwiss stations located within Cantone Ticino (with the exception of S. Bernardino and Grono ones) with annual average values measured at a distance of $2 \mathrm{~m}$ above ground and homogenized over the 1981-2010 period were considered for the development of the MAAT map. Table 2 shows the location of the used monitoring stations and the corresponding MAAT values.

Table 2. Information regarding Cantone Ticino's MeteoSwiss stations used for Mean Annual Air Temperature (MAAT) map creation.

\begin{tabular}{ccccc}
\hline \multirow{2}{*}{ Station Name } & \multicolumn{2}{c}{ Spatial Information } & $\begin{array}{c}\text { Normal Period: 1981-2010 } \\
\text { (Datum: WGS 84) }\end{array}$ \\
\cline { 2 - 5 } & $\begin{array}{c}\text { Latitude } \\
\text { (Decimal Degrees) }\end{array}$ & $\begin{array}{c}\text { Longitude } \\
\text { (Decimal Degrees) }\end{array}$ & $\begin{array}{c}\text { Altitude } \\
\text { (m a.s.1.) }\end{array}$ & Measured MAAT ( ${ }^{\circ}$ C) \\
\hline Lugano & 46.0042 & 8.9603 & 273 & 12.4 \\
Stabio & 45.8434 & 8.9323 & 353 & 11.1 \\
Cimetta & 46.2004 & 8.7916 & 1661 & 5.2 \\
Locarno Monti & 46.1724 & 8.7875 & 367 & 12.4 \\
Magadino/Cadenazzo & 46.1600 & 8.9336 & 203 & 11.4 \\
Grono & 46.2550 & 9.1637 & 324 & 12.4 \\
Acquarossa/Comprovasco & 46.4595 & 8.9354 & 575 & 9.9 \\
Piotta & 46.5148 & 8.6880 & 990 & 7.7 \\
S.Bernardino & 46.4635 & 9.1846 & 1639 & 3.9 \\
\hline
\end{tabular}

The mapping procedure was performed at a small region-scale, so only the effects of altitude were taken into account without considering latitude. A linear regression between altitude data and temperature data was performed, finding a regression formula with a Pearson $\mathrm{R}^{2}$ factor of 0.95 
that led to an error of approximately $7.4 \%\left(0.65^{\circ} \mathrm{C}\right)$ between measured and estimated temperature. The discovered linear equation was:

$$
\text { M.A.A.T. }\left({ }^{\circ} \mathrm{C}\right)=\frac{\text { Altitude }-2385.7}{-174.61}
$$

The formula was applied to a $25 \mathrm{~m}$ Digital Elevation Model (DEM), obtaining the MAAT map for Cantone Ticino (Supplementary Material Figure S1).

As expected, valleys show higher mean annual air temperatures and this reflects on annual ground temperatures. In literature, as a good approximation, MAAT is commonly considered as equal to the undisturbed ground temperature $[19,20]$. Ground temperatures maps are therefore usually derived by creating MAAT maps. To understand if this assumption could be valid for an Alpine region like the studied one, MAAT map was compared with undisturbed ground temperatures obtained from Thermal Response Tests (TRTs) executed in the region between 2010 and 2015 at different altitudes. For this specific case the absolute average shift between MAAT and undisturbed ground temperature was quantified in $2.3^{\circ} \mathrm{C}$ as seen in Table 3 .

Table 3. Comparison between undisturbed ground temperatures from thermal response tests (TRTs) and MAAT.

\begin{tabular}{|c|c|c|c|c|c|c|}
\hline Site Name & $\begin{array}{l}\text { Lat. (DD, } \\
\text { WGS84) }\end{array}$ & $\begin{array}{l}\text { Long. [DD, } \\
\text { WGS 84] }\end{array}$ & $\begin{array}{l}\text { Altitude } \\
\text { (m a.s.1.) }\end{array}$ & $\begin{array}{l}\text { Undisturbed Ground } \\
\text { Temperature from } \\
\text { TRT }\left({ }^{\circ} \mathrm{C}\right)\end{array}$ & $\begin{array}{l}\text { Estimated } \\
\text { MAAT from } \\
\text { Map }\left({ }^{\circ} \mathrm{C}\right)\end{array}$ & $\begin{array}{c}\text { Absolute T } \\
\text { Discrepancy } \\
\left({ }^{\circ} \mathrm{C}\right)\end{array}$ \\
\hline Collina d'oro & 45.9631 & 8.9083 & 526 & 11.8 & 10.7 & 1.1 \\
\hline Lugano-Besso & 46.0094 & 8.9380 & 378 & 14.8 & 11.5 & 3.3 \\
\hline Massagno & 46.0115 & 8.9423 & 367 & 14.8 & 11.6 & 3.2 \\
\hline $\begin{array}{c}\text { Olivone } \\
\text { (estimated } \\
\text { coordinates) }\end{array}$ & 46.5181 & 8.8842 & 1433 & 8.3 & 5.5 & 2.8 \\
\hline \multicolumn{5}{|c|}{ DATA SOURCE: various TRT executed in-situ between 2010 and 2015} & MAE: $2.3^{\circ} \mathrm{C}$ & RMSE: $2.5^{\circ} \mathrm{C}$ \\
\hline
\end{tabular}

This proved that the produced MAAT map was not suitable to be used as a ground temperature map. The magnitude of the measured gap between MAAT and GST depends on snow cover and on the latent heat of fused ground moisture [24]. GST greatly affects the heat exchange between the probe and the surrounding ground, so a careful evaluation is required. A correction factor taken from Swiss regulation was therefore applied on the created MAAT map in order to derive a GST one. According to SIA 384/6, which is the Swiss regulation for closed-loop systems, the investigated region was then subdivided into two portions, depending on elevation classes. For a pixel elevation $<1000 \mathrm{~m}$, the equation used for GST estimate was:

$$
\mathrm{GST}=\mathrm{MAAT}+1.55^{\circ} \mathrm{C}
$$

For an elevation $>1000 \mathrm{~m}$, the equation was:

$$
\mathrm{GST}=\mathrm{MAAT}+1.55^{\circ} \mathrm{C}+\frac{(\text { Altitude }-1000)}{800} \times 2.45
$$

Results from the GST mapping procedure are shown in Figure 3. Five soil monitoring stations taken from [25] were used in order to compare the proposed reconstruction of GST with real measured data. Measured GST data consist of short time series of soil temperatures, aggregated monthly, at $0.1 \mathrm{~m}$ depth. Data comparison between mapped and measured GST is reported in Table 4. 

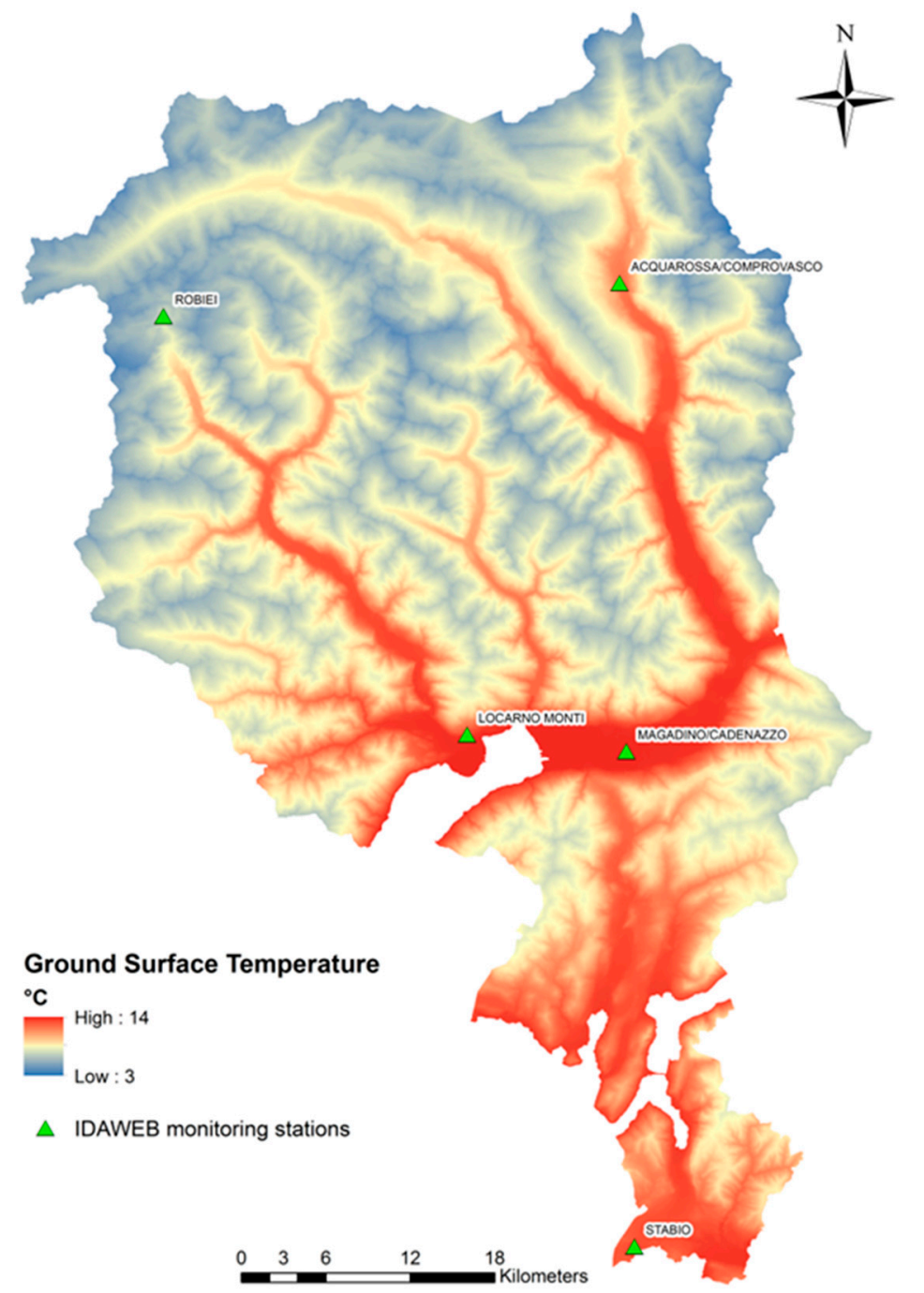

Figure 3. Map of reconstructed ground surface temperature (GST) with highlighted IDAWEB stations used for comparison between measured and estimated GST.

Table 4. Comparison between measured and estimated GST.

\begin{tabular}{|c|c|c|c|c|c|c|c|}
\hline Site Name & $\begin{array}{l}\text { Lat. (DD, } \\
\text { WGS84) }\end{array}$ & $\begin{array}{l}\text { Long. (DD, } \\
\text { WGS84) }\end{array}$ & $\begin{array}{l}\text { Altitude } \\
\text { (m a.s.l.) }\end{array}$ & Consistency & $\begin{array}{l}\text { Measured } \\
\text { GST }\left({ }^{\circ} \mathrm{C}\right)\end{array}$ & $\begin{array}{l}\text { Mapped } \\
\text { GST }\left({ }^{\circ} \mathrm{C}\right)\end{array}$ & $\begin{array}{c}\text { Absolute } \\
\text { Discrepancy }\left({ }^{\circ} \mathrm{C}\right)\end{array}$ \\
\hline $\begin{array}{l}\text { Acquarossa/ } \\
\text { Comprovasco }\end{array}$ & 46.4594 & 8.9356 & 575 & $\begin{array}{l}\text { Average value } \\
\text { for } 3 \text { years }\end{array}$ & 10.6 & 11.9 & 1.3 \\
\hline $\begin{array}{l}\text { Locarno } \\
\text { monti }\end{array}$ & 46.1725 & 8.7874 & 366 & $\begin{array}{l}\text { Average values } \\
\text { for } 9 \text { years }\end{array}$ & 13.6 & 13.1 & 0.5 \\
\hline $\begin{array}{l}\text { Magadino/ } \\
\text { Cadenazzo }\end{array}$ & 46.1600 & 8.9336 & 203 & $\begin{array}{l}\text { Average value } \\
\text { for } 12 \text { years }\end{array}$ & 12.7 & 14.0 & 1.3 \\
\hline Robiei & 46.4430 & 8.5133 & 1896 & $\begin{array}{l}\text { Average value } \\
\text { for } 6 \text { years }\end{array}$ & 5.1 & 7.1 & 2.0 \\
\hline Stabio & 45.8433 & 8.9323 & 353 & $\begin{array}{l}\text { Average value } \\
\text { for } 4 \text { years }\end{array}$ & 11.8 & 13.2 & 1.4 \\
\hline \multicolumn{6}{|c|}{ Data source: IDAWEB [25] } & MAE: $1.3{ }^{\circ} \mathrm{C}$ & RMSE: $1.4{ }^{\circ} \mathrm{C}$ \\
\hline
\end{tabular}

The $\mathrm{R}^{2}$ coefficient for the linear regression is 0.94 , the overall discrepancy between measured and mapped GST can be defined as $\pm 1.3^{\circ} \mathrm{C}$, with an RMSE of $1.4^{\circ} \mathrm{C}$. A second verification process was then performed: resulting GST map was compared with a robust approach proposed by Signorelli and Kohl (2004) for GST mapping calibrated for the entire Switzerland and valid for elevations $\leq 1500 \mathrm{~m}$ a.s.l. [24]. In the cited study the Swiss GST map was obtained by analyzing ground temperature data from 1984 to 2004 and determining GST dependence with altitude and with surface air temperature. A GST map 
was then built and verified against ground temperature values obtained by extrapolation from a large number of boreholes. Signorelli and Kohl's polynomial regression for elevations $\leq 1500 \mathrm{~m}$ a.s.l. was applied to the DTM:

$$
\text { GST }=15.23-1.08 \times 10^{-2} \times(\text { Elevation })+5.61 \times 10^{-6} \times(\text { Elevation })^{2}-1.5 \times 10^{-9} \times(\text { Elevation })^{3}
$$

Stations above $1500 \mathrm{~m}$ a.s.l. were not considered for this approach, since over this altitude the polynomial regression is not reliable according to what they state in [24]. This comparison showed that GST reconstruction of the present paper was not dissimilar from the polynomial regression of Signorelli and Kohl. Giving this double comparison process, the produced GST map was considered to be suitable for further elaborations. More measured data could surely improve the reliability of this GST reconstruction.

\subsection{Subsurface Thermal Characterization}

The subsequent step was devoted to the thermal characterization of the subsurface, which is of fundamental importance when estimating a techno-economic shallow geothermal potential. To derive a thermal conductivity map the territory was split into two separate portions, depending on material type: outcrops and unconsolidated materials within monitored aquifers. The thermal characterization of these two subsets required different mapping approaches.

\subsubsection{Outcrops}

Thermal conductivity map of outcrops was built by using a 1:500,000 scale geological map provided by [26]. Recommended values of thermal conductivity were assigned to each specific lithology according to SIA 384/6; in presence of multiple lithologies within the same polygon, an average value of recommended thermal conductivity was assigned. Dolomite and Vulcanites outcropping lithologies in southern Ticino were assigned thermal conductivity values according to [27], where $\lambda$ measurements were performed in laboratory on field samples. The assigned thermal properties are reported in Table 5. Thermal conductivity map of outcrops was compared with five TRTs performed in predominant rock (Supplementary Material Table S1). Results show that the mapped estimated thermal conductivity is lower in almost all locations (average error $=+1 \mathrm{~W} / \mathrm{mK}$ ). A thermal conductivity map at this scale cannot consider local anomalies, heterogeneities or local groundwater flow which affect (frequently improve) thermal properties of the subsurface. This could imply that the mapped estimated conductivities could be systematically underestimated and the required BHE slightly overestimated.

Table 5. Thermal characterization of outcrops and unmonitored Quaternary portion for in Cantone Ticino.

\begin{tabular}{ccc}
\hline Lithology & $\lambda(\mathbf{W} / \mathbf{m K})$ & Data Source \\
\hline Greenschists, amphibolites, metagabbro, meta-ultrabasite & 2 & Averaged from SIA 384/6 \\
Pelitic and psammitic gneiss, fillads, conglomerates, sandstone & 2.6 & Averaged from SIA 384/6 \\
Dolomite and dolomitic marble & 3.17 & Lab. measurements Soma, 2015 \\
Granite, granodiorite & 2.8 & SIA 384/6 \\
Acid and basic vulcanites & 2.36 & Lab. measurements Soma, 2015 \\
Granite gneiss & 2.7 & SIA 384/6 \\
Generic Quaternary deposits & 2 & Representative value SIA 384/6 \\
\hline
\end{tabular}

\subsubsection{Unconsolidated Materials}

Only the main monitored aquifers were taken into account for the characterization of the unconsolidated portion: Magadino plain, Laveggio, Vedeggio, Valle Maggia and Chiasso. The used approach consisted in mapping the hydraulic conductivity and the shape of the groundwater table for 
each aquifer. The first reconstruction was useful to assign appropriate thermal properties to each zone, while the second reconstruction was useful to assess the depth of the groundwater.

The thickness of the vadose zone influences both the thermal conductivity of the subsurface and therefore the heat transfer rate as experimentally demonstrated in [28]. For monitored aquifers the shape of the water table between 2015 and 2017 was reconstructed by using mean annual hydraulic head data retrieved from a groundwater monitoring network composed of 110 monitoring points (10 automatic probes and approximately 100 piezometers/water wells). Groundwater data was used to estimate the thicknesses of both vadose zone and saturated portion considering a total of $100 \mathrm{~m}$ depth, which is commonly the typical depth of Borehole Heat Exchangers (BHEs). Using a wet/dry approach allows to more accurately describe the influence of vadose zone on $\lambda$ values. This correction factor does not greatly affect zones with shallow groundwater but it is fundamental for deeper groundwater zones, such as alluvial fans.

The main assumption of the hydraulic conductivity map was that values obtained from pumping tests (in form of $\log 10 \mathrm{k}$ and the back-transformed $\mathrm{k}$, where $\mathrm{k}$ is the hydraulic conductivity) could be considered as representative of all the subsurface column down to $100 \mathrm{~m}$ depth. This assumption is congruent with a mapping procedure for a $2800 \mathrm{~km}^{2}$ region with output maps scale of approximately 1:400,000-1:500,000. Bedrock occurrences within $100 \mathrm{~m}$ depth were not considered, since not enough bedrock depth information (only few logs for all aquifers) was available. 556 hydraulic conductivity values measured from pumping tests were therefore analyzed and $\log _{10} \mathrm{k}$ was computed. If some wells showed more than one value of measured $\mathrm{k}$ ( 15 of 556) at different depths, logk averaging was performed. The computed hydraulic conductivity values were interpolated to create a continuous reconstruction. Ordinary kriging was chosen to interpolate between wells, since no trend within data was observed. The parameters used for both the realization of the experimental variogram and for the interpolation are reported in Table 6. The interpolated data were back-transformed using the $\mathrm{k}$ $=10^{\text {logk }}$ relation. In order to assess the goodness and the reliability of the proposed reconstruction, two verification steps were performed. Firstly a leave-one-out cross-validation was performed using the same dataset used for the interpolation. Then a second dataset of measured logk was used to compare the results: this second dataset is constituted of 409 surveys distributed fairly homogeneously within the whole investigated area. Results of the comparison between the interpolated hydraulic conductivity and the second dataset are reported in Table 6.

Table 6. Ordinary kriging parameters (left) and cross-validation/comparison with real data (right) for hydraulic conductivity spatial reconstruction.

\begin{tabular}{cc|ccc}
\hline \multicolumn{1}{c|}{ Variogram } & & \multicolumn{2}{c}{ Double Comparison Statistics } \\
\hline Parameter & Value & & Cross Validation & Surveys Data \\
\hline Nugget & 0.247 & $\mathrm{~N}^{\circ}$ of data & 555 & 409 \\
Range $(\mathrm{m})$ & 1514 & Max Abs error $\left(\log _{\mathrm{k}}\right)$ & 3.51 & 2.26 \\
Sill (Partial) & $4.08(0.161)$ & Min Abs error $\left(\log _{\mathrm{k}}\right)$ & 0.00039 & 0.000704 \\
Model & Spherical & Average error $\left(\log _{\mathrm{k}}\right)$ & 0.00076 & -0.09371 \\
Lag size $(\mathrm{m})$ & 322.3 & MAE $\left(\log _{\mathrm{k}}\right)$ & 0.46 & 0.49 \\
$\mathrm{~N}^{\circ}$ of lags & 12 & MSE $\left(\log _{\mathrm{k}}\right)$ & 0.37 & 0.43 \\
Neighbors to include & 30 & RMSE $\left(\log _{\mathrm{k}}\right)$ & 0.61 & 0.66 \\
- & - & NRMSE $\left(\log _{\mathrm{k}}\right)$ & 0.11 & 0.15 \\
\hline
\end{tabular}

The target error to be achieved was a global error below 1 order of magnitude and preferably close to 0.5 orders of magnitude. In particular it was assumed that an error between measured and predicted $\log _{10} \mathrm{k}$ ranging from 0 to 0.4 could represent a proper estimate of $\mathrm{k}$ value, while values of $\log _{10} \mathrm{k}$ error between 0.4 and 0.7 could lead to a reasonable approximation of $\mathrm{k}$ values; values over 0.7 and 1.5 were symptoms respectively of bad and very bad estimates. The results were quite satisfactory since the MAE and RMSE were near $0.6 \log _{10} \mathrm{k}$ orders of magnitude for both tests.

A reliability map was then created where deviation between measured and estimated values of hydraulic conductivity at different locations was reported. By using the aforementioned classification, 
$53 \%$ of the points (217 pts) were classified as "Good" (abs. error $<0.4$ ), while $22.5 \%$ (92 pts) were classified as "Sufficient" (error between 0.4 and 0.7). The remaining 24.5\% (100 pts) was classified as "Insufficient" or "Bad", since high errors were observed.

Observation classified as "Bad" are mainly located in the southern part, especially in Chiasso (2 values over 1.5), Stabio ( $3 \mathrm{pts}$ ) and Mendrisio (1 pt) (Supplementary Material: Figure S2). The interpolation reliability here is poor because of the few hydraulic conductivity data available in this aquifer so the results in this location have to be seen considering a greater bias.

The reconstruction of hydrogeological properties was the starting point for the thermal characterization of Quaternary deposits within monitored aquifers. Deposits were divided into fine, medium and coarse litho-textures, according with $[29,30]$ representative values of hydraulic conductivity, corresponding respectively to silt, sand and gravel. Hydraulic conductivity values between 1 and $10^{-3} \mathrm{~m} / \mathrm{s}$ were considered as "gravel", k between $10^{-3}$ and $10^{-4} \mathrm{~m} / \mathrm{s}$ was considered as "sand" deposits and all other deposits showing k values below $10^{-5} \mathrm{~m} / \mathrm{s}$ were considered as "silt". Through this approach $58 \%$ of the aquifers were classified as gravelly, while the remaining portion was classified as sands (39\%) and clays (3\%).

The classified unconsolidated deposits were thermally characterized by assigning to each lithological class a referential $\lambda$ value for both a completely wet and completely dry scenario $(\lambda$ wet and $\lambda$ dry). This approach was adopted since there are zones located mainly in the northern part of the study area (north of Magadino Plain) and in alluvial fans that are characterized by great groundwater depth. The weighted $\lambda$ for each pixel was spatially estimated to be:

$$
\text { weighted } \lambda=\frac{[(\lambda \text { dry } * \text { unsaturated thickness }+\lambda \text { wet } * \text { saturated thickness }]}{100 \mathrm{~m}}
$$

A reference bottom elevation for the aquifer of $100 \mathrm{~m}$ below ground surface was adopted since no specific data regarding bedrock depth was available. A thermal conductivity of $2 \mathrm{~W} / \mathrm{mK}$ was assigned to generic Quaternary deposits not belonging to monitored aquifers; it is a reasonable value given the low groundwater depth and the coarse-grained lithologies observed within the subsurface of Cantone Ticino (Table 5). Gravels were assigned a dry thermal conductivity of $0.4 \mathrm{~W} / \mathrm{mK}, 1.7 \mathrm{~W} / \mathrm{mK}$ for completely saturated medium. Sands and silts were assigned respectively a dry/wet thermal conductivity of $0.5 / 2.3 \mathrm{~W} / \mathrm{mK}$ and $0.6 / 1.4 \mathrm{~W} / \mathrm{mK}$.

The results of thermal conductivity reconstruction for both outcrops and sediments are reported in Figure 4. Only one TRT data within unconsolidated material was available for the validation (Supplementary Material: Table S1). The TRT, located near Mendrisio (Laveggio aquifer), returned a $\lambda$ value of $2.2 \mathrm{~W} / \mathrm{mK}$, while the mapped $\lambda$ reconstruction returned a value of $1.7 \mathrm{~W} / \mathrm{mK}$ in the same location. The error was therefore quantified in $27 \%$ which could be due to the convective contribution of groundwater flow, neglected in this study. A more detailed thermal characterization of the underground through real data would improve the map modeling and the final results. 


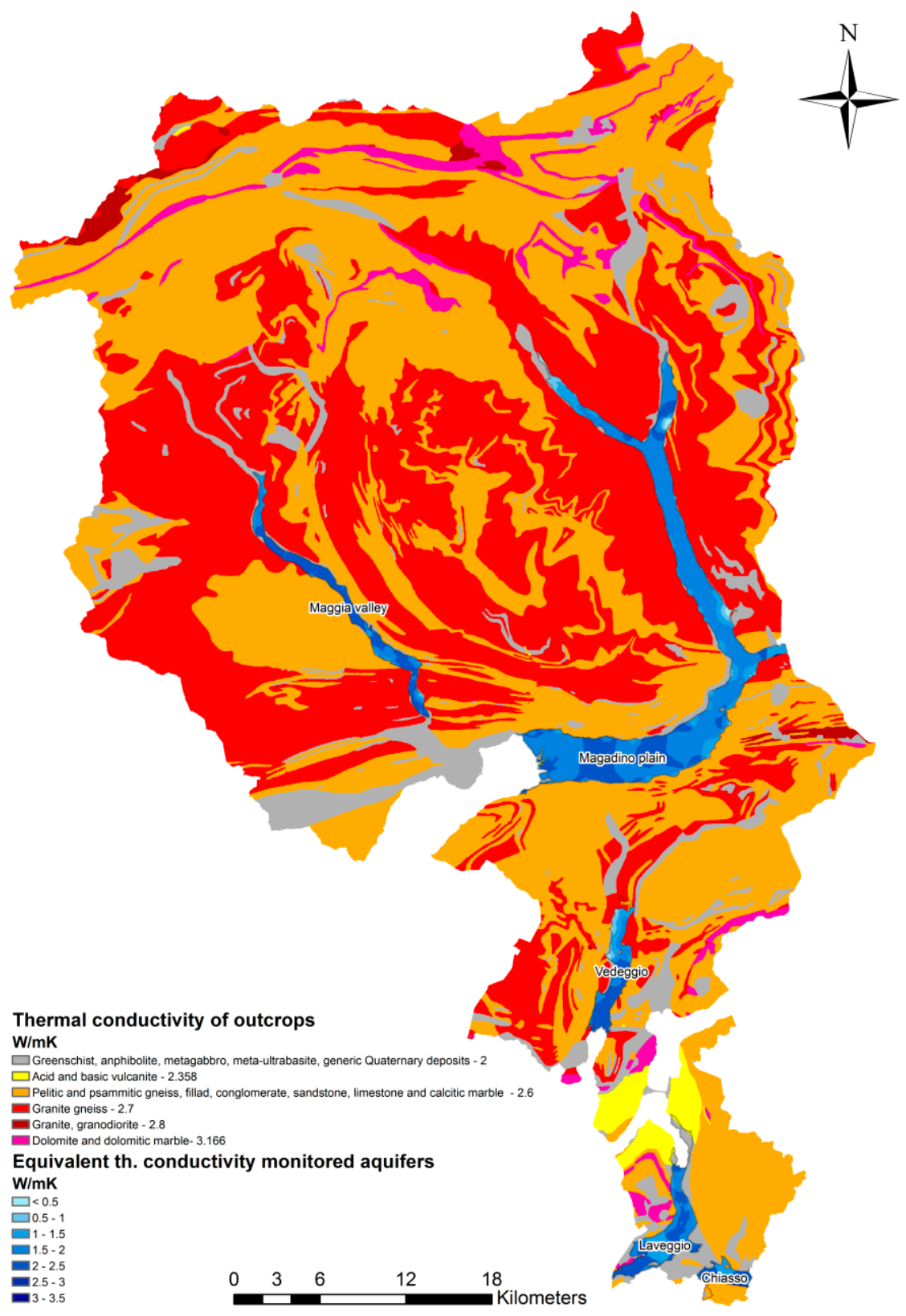

Figure 4. Spatial reconstruction of Cantone Ticino thermal conductivity: red shades belong to outcrops of different lithologies, while blue shades represent monitored aquifers. The names of the monitored aquifers are reported in the map.

\section{Technological Constraints}

\subsection{Target GSHP System Characteristics}

The estimation of BHE length is strictly connected to the identification of a reference residential unit that could represent a target building. A residential unit composed of 5 flats of $100 \mathrm{~m}^{2}$ each $\left(500 \mathrm{~m}^{2}\right.$ total) that represents the average surface of a flat located in Cantone Ticino was chosen as referential. The multi-family unit was chosen because it is the most common residential type of building observed according to [31]; moreover the Cantonal energy master plan is designed considering a multi-family residential building whose heating is provided by heating oil [32]. The referential GSHP system has been identified in a four probe installation, with a heating capacity of $25 \mathrm{~kW}$, as previously described in Section 1.1. 


\subsection{Hypothesized Energy Demand}

An energetic index of $60 \mathrm{kWh} / \mathrm{m}^{2}$.year was used as referential to estimate both the annual heat demand and the hot sanitary water (HSW) demand. A MINERGIE ${ }^{\circledR}$ energy standard for refurbished buildings and not for new ones ( $38 \mathrm{kWh} / \mathrm{m}^{2}$.year) was chosen in order to stay conservative and to avoid the underestimate of the obtained output BHE length.

MINERGIE $^{\circledR}$ is a quality label used both for new and refurbished buildings that promotes a rational use of energy, the use of renewables and emission savings. This quality label is required for Cantonal or Confederation new buildings. The chosen MINERGIE ${ }^{\circledR}$ index represents the energy demand for buildings that were built before 2000 and are planned to be refurbished.

The product of the MINERGIE ${ }^{\circledR}$ index $\left(60 \mathrm{kWh} / \mathrm{m}^{2}\right.$.year) for the considered reference area $\left(500 \mathrm{~m}^{2}\right)$ resulted in $30 \mathrm{MWh} /$ year including domestic hot water: the complete estimated monthly energy profile is reported in Table 7. A summer cooling demand was not taken into account mainly because it could reinstate the thermal field, resulting in COP improvements and reduced simulated BHE length. This is justified since the climate classification for Cantone Ticino is $\mathrm{Cfb}$ (wet temperate climate with average summer temperatures $<22{ }^{\circ} \mathrm{C}$ ) therefore the cooling demand is low compared with the heating one, having long winter period and brief summer period.

Table 7. Referential geothermal system parameters and values used in earth energy designer (EED) simulations.

\begin{tabular}{|c|c|c|c|c|c|c|c|c|c|c|c|c|}
\hline Input & \multicolumn{5}{|c|}{ Parameter } & \multicolumn{7}{|c|}{ Value } \\
\hline & \multicolumn{5}{|c|}{ Probe type } & \multicolumn{7}{|c|}{ Double-U tube } \\
\hline & \multicolumn{5}{|c|}{ Configuration } & \multicolumn{7}{|c|}{$2 \times 2\left(\mathrm{~N}^{\circ} 233\right)-4$ probes } \\
\hline & \multicolumn{5}{|c|}{ Distance } & \multicolumn{7}{|c|}{$8 \mathrm{~m}$} \\
\hline & \multicolumn{5}{|c|}{ Borehole diameter } & \multicolumn{7}{|c|}{$130 \mathrm{~mm}$} \\
\hline Heat exchanger & \multicolumn{5}{|c|}{ Grouting thermal conductivity } & \multicolumn{7}{|c|}{$1 \mathrm{~W} / \mathrm{mK}$} \\
\hline and perforation & \multicolumn{5}{|c|}{ Volumetric flow rate } & \multicolumn{7}{|c|}{$21 /$ s per probe } \\
\hline & \multicolumn{5}{|c|}{ Probe external diameter } & \multicolumn{7}{|c|}{$32 \mathrm{~mm}$} \\
\hline & \multicolumn{5}{|c|}{$\begin{array}{c}\text { Thickness } \\
\text { Probes thermal }\end{array}$} & \multicolumn{7}{|c|}{$3 \mathrm{~mm}$} \\
\hline & \multirow{2}{*}{\multicolumn{5}{|c|}{$\begin{array}{l}\text { Probes thermal conductivity } \\
\text { Distance between internal tubes }\end{array}$}} & \multirow{2}{*}{\multicolumn{7}{|c|}{$\begin{array}{l}0.420 \mathrm{~W} / \mathrm{mK} \\
80 \mathrm{~mm}\end{array}$}} \\
\hline & & & & & & & & & & & & \\
\hline \multirow{5}{*}{$\begin{array}{l}\text { Thermo-vector } \\
\text { fluid }\end{array}$} & \multicolumn{5}{|c|}{ Thermal conductivity } & \multicolumn{7}{|c|}{$0.48 \mathrm{~W} / \mathrm{mK}$} \\
\hline & \multicolumn{5}{|c|}{ Specific heat } & \multicolumn{7}{|c|}{$3795 \mathrm{~J} / \mathrm{kgK}$} \\
\hline & \multicolumn{5}{|c|}{ Density } & \multicolumn{7}{|c|}{$1052 \mathrm{~kg} / \mathrm{m} 3$} \\
\hline & \multicolumn{5}{|c|}{ Viscosity } & \multicolumn{7}{|c|}{$0.0052 \mathrm{~kg} / \mathrm{ms}$} \\
\hline & & & ezing & & & & & & $-14^{\circ} \mathrm{C}$ & & & \\
\hline & Const & int valu & & & & & & & & & & \\
\hline Probes thermal & & Between & luid a & groun & & & & & $40 \mathrm{mK} /$ & & & \\
\hline resistance & $\begin{array}{l}- \\
\text { Takes }\end{array}$ & $\begin{array}{l}\text { nternal } \\
\text { nto acc }\end{array}$ & unt int & nal hec & fluxes & & & & $50 \mathrm{mK} /$ & & & \\
\hline Heating capacity & & & - & & & & & & $25 \mathrm{~kW}$ & & & \\
\hline & & & & & & & & & 4 & & & \\
\hline Performance & & Annura & SPF & loman & & & & & $0 \mathrm{MWh}$ & & & \\
\hline Energetic demand & & Annua & neatin & SWman & & & $2.5 \mathrm{M}$ & $\mathrm{Jh} /$ yea & r provi & ed by & ground & \\
\hline & & & & & & & MWl & /year & rovide & by he & at pum & \\
\hline & Jan. & Feb. & Mar. & Apr. & May & Jun. & Jul. & Aug. & Sept. & Oct. & Nov. & Dec. \\
\hline $\begin{array}{l}\text { Heating demand } \\
\text { [MWh/month] }\end{array}$ & 4.65 & 4.44 & 3.75 & 2.97 & 1.92 & 0 & 0 & 0 & 1.83 & 2.61 & 3.51 & 4.32 \\
\hline $\begin{array}{l}\text { Peak monthly } \\
\text { heating duration } \\
\text { [hours/month] }\end{array}$ & 6 & 5 & 5 & 3 & 3 & 0 & 0 & 0 & 3 & 3 & 5 & 6 \\
\hline
\end{tabular}




\section{Results}

\subsection{Required BHE Length Calculation}

EED software was developed by Lund University for the modeling of vertical BHEs. In very large and complex projects, EED allows for retrieving the optimized required borehole length and layout before starting more detailed analyses. EED is based on $g$-functions, which depend on the spacing between the boreholes and on the borehole depth. In this paper EED was used to simulate 128 scenarios using a fixed set of system parameters that could represent a referential GSHP system (Table 7) where alternately GST, $\lambda$, heat flux and volumetric heat capacity were changed (Supplementary Material Table S3). The range of the values for each parameter partially represents the variability of each value within the mapped areas, but only the most frequent values observed in the most populated zones were taken into account. GST values from 3 to $10{ }^{\circ} \mathrm{C}$ were not considered in the simulations because the majority of the closed-loop systems in Ticino are located in zones where GST lies between 11 and $14{ }^{\circ} \mathrm{C}$, therefore adding simulations for these locations would have been redundant. The choice of the intervals was also made in order to speed up computational times, avoiding the realization of thousands of simulations that would have not significantly contributed to the identification of the regression polynomial function. This described procedure allowed creating a good number of scenarios resulting in BHE length values that could be put into relation with GST and $\lambda$ values (which were previously mapped in Cap. 2). 3D correlation between thermal conductivity, GST and required BHE length was better described by a 2nd grade polynomial function which produces a $\mathrm{R}^{2}$ of 0.95 and a RMSE of 16 m (Supplementary Material: Figure S3 and Table S2):

$$
\text { Required BHE length }=1236-269.1 * \lambda-34.83 * \mathrm{GST}+34 * \lambda^{2}+2.47 * \lambda * \mathrm{GST}
$$

This polynomial regression was applied to GST and $\lambda$ maps in order to obtain a continuous estimate of BHE length for the previously defined reference building. The resulting map of required BHE length (Figure 5) shows that the potential is lower where the altitude is higher because it is strongly affected by the annual temperature of the underground. A higher potential is mainly located within the major valleys of Cantone Ticino, due to higher annual temperatures and due to the presence of groundwater at low depth. These areas are also affected by restrictions due to the presence of groundwater protection zones, which do not allow a complete deployment of new GSHP systems. The white spots represent the large number of lakes located within Cantone Ticino: there the potential was not mapped.

To understand the reliability of this map the estimated BHE length of the map was compared with the real installed length observed in Ticino for 51 verified systems where heating demand is prevalent. These GSHPs are almost completely located in a portion of territory below $1000 \mathrm{~m}$ of altitude, but also four systems installed above $1000 \mathrm{~m}$ were observed. To perform this comparison, standardization for the installation power and for the number of probes was executed using the following proportion:

$$
\text { Real length }=\frac{\text { estimated required BHE length } * \text { real system power }}{25 \mathrm{~kW}}
$$

The BHE length estimated by the map has been corrected for the installed power. This proportion is possible because a linear correlation between cumulative installed BHE length and system power was observed within Cantone Ticino: the resulting map represents the amount of meters needed to obtain $1 \mathrm{~kW}$ of installed heating power $(\mathrm{m} / \mathrm{kW}$ map). The comparison between measured/stated values of $\mathrm{m} / \mathrm{kW}$ and estimated ones, reported in Figure $6 \mathrm{a}$ and Table 8 , show that installations with an estimated error $\leq 10 \%$ (27.4\% of the total, 14 systems) are located homogeneously within the study area, from North to South and from West to East. 20 systems show an error between 10 and 25\% (39.2\% of the total), 14 systems (27.4\% of the total) show a \% error between 25 and 50, while the remaining three systems show values above $50 \%$ of error ( $6 \%$ of the total). 


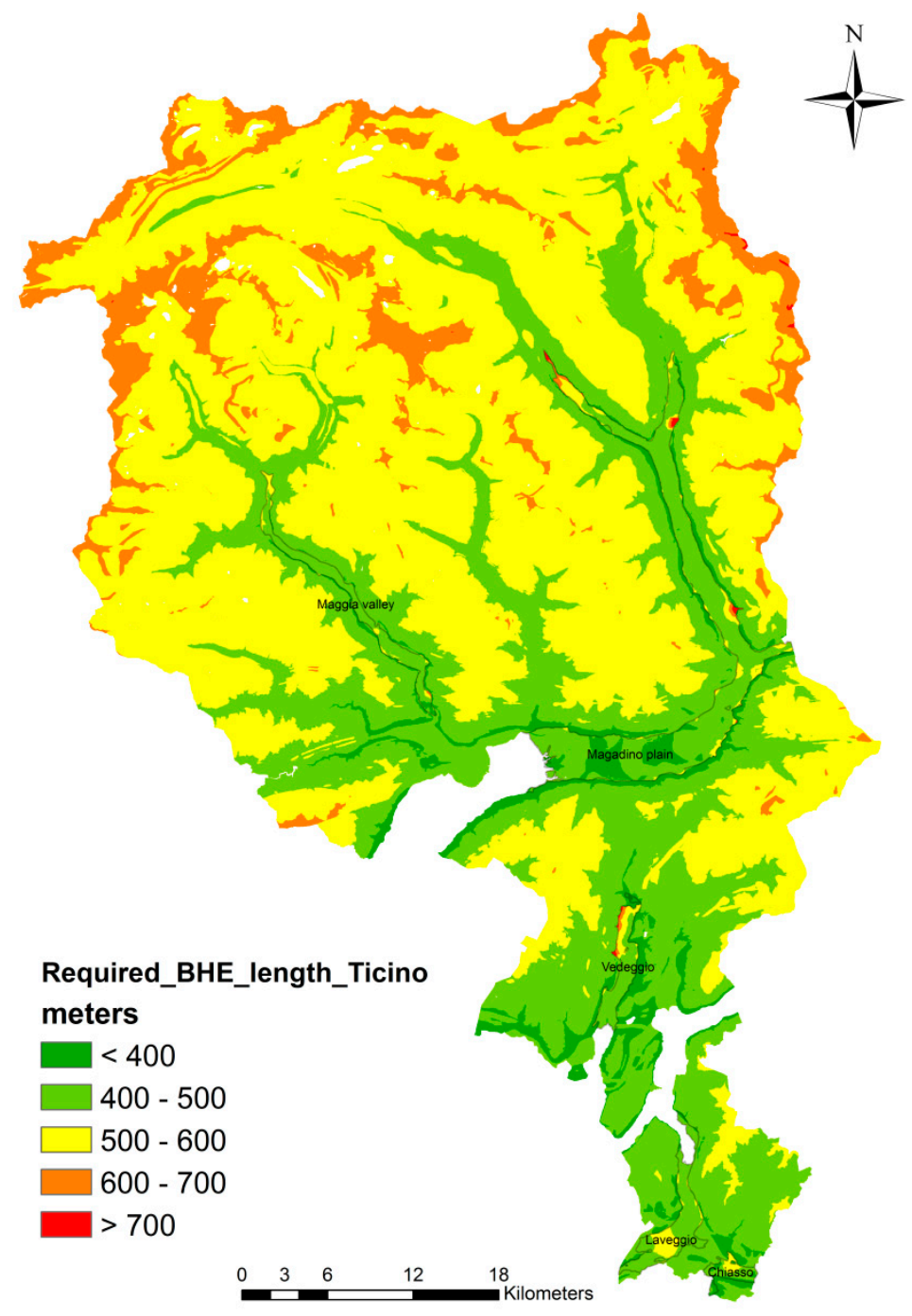

Figure 5. Map of required BHE length to satisfy the imposed energy demand of the referential refurbished MINERGIE ${ }^{\circledR}$ building considered in the simulations.

Table 8. Comparison statistics between measured and computed borehole heat exchanger (BHE) lengths.

\begin{tabular}{cc}
\hline Statistic & Value \\
\hline Max abs error & $52 \mathrm{~m} / \mathrm{kW}$ \\
Min abs error & $1 \mathrm{~m} / \mathrm{kW}$ \\
Average error & $3.7 \mathrm{~m} / \mathrm{kW}$ \\
Mean abs error & $6 \mathrm{~m} / \mathrm{kW}$ \\
Abs average error $(\%)$ & $\pm 23 \%$ \\
\hline
\end{tabular}

Basically the same results were also obtained for systems above $1000 \mathrm{~m}$ of altitude: the method can be therefore reliable for different ranges of elevation. Results globally show that the created map has a semi-quantitative value at regional scale, with an overall average error of $23 \%$ equivalent to $\pm 6 \mathrm{~m} / \mathrm{kW}$. Considering that the test area is approximately $3000 \mathrm{~km}^{2}$ wide, results are satisfactory. The less performant aquifer results to be Laveggio, which requires on average $18.4 \mathrm{~m}$ to provide $1 \mathrm{~kW}$ of installed capacity, while the most performant aquifer is Chiasso, requiring on average $17.4 \mathrm{~m} / \mathrm{kW}$. These values must be considered by taking into account the incertitude of the estimated $\mathrm{m} / \mathrm{kW}$ map, which is $\pm 23 \%$. Starting from this premise the estimated aquifers potential results to be quite similar: a general uniformity of geo-exchange potential can be hypothesized. 

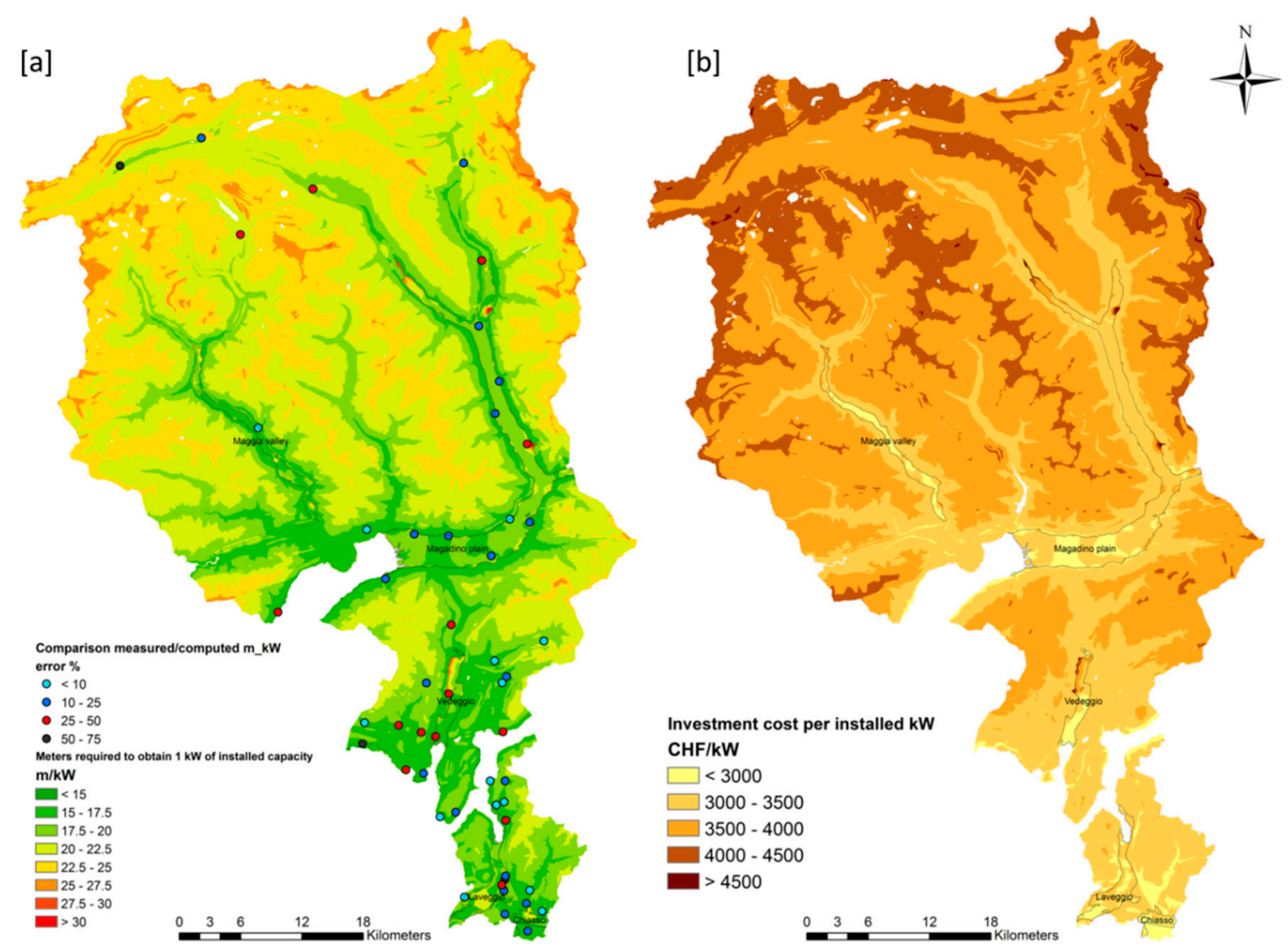

Figure 6. Map of (a) estimated meters required to obtain $1 \mathrm{~kW}$ of installed power and (b) specific capital cost expressed as $\mathrm{CHF} / \mathrm{kW}$.

\subsection{Economical Maps}

\subsubsection{Total Installation Costs and $\mathrm{CHF} / \mathrm{Kw}$}

Another interesting topic was related to the estimation of an overall cost of the hypothesized GSHP referential system depending on its length. Different drillability values to each macro-lithology observed within Cantone Ticino and reported in Table 9 were assigned. These costs data came from an estimate made by SUPSI in collaboration with a drilling company. Drilling costs are approximately quantified between a minimum of $60 \%$ of the total installation costs for consolidated sedimentary rocks and a maximum of $84 \%$ for hard rocks. Drilling into hard volcanic rocks would cost more than drilling into sediments or sedimentary rocks. Probe cost and grouting costs refer to the installation of a double-U probe, which is the most common probe type used in Cantone Ticino. Labor costs are approximately quantified in $4 \%$ of the total cost while the disposal of the drilling mud in a controlled landfill (mandatory for Switzerland) represents $7 \%$ of the total cost. All these information plus estimates of labor costs and mud disposal were implemented in GIS environment and an installation costs map was produced (Figure 6b). Cost estimates have to taking into account an average error of $\pm 23 \%$ in $\mathrm{m} / \mathrm{kW}$ evaluation. The final cost estimate including labor costs and mud disposal ranges from 70,000 CHF to $133,000 \mathrm{CHF}$ for the identified referential residential system. At the moment of writing, $1 \mathrm{CHF}$ or Swiss Franc is equal to $0.87 €$. This means that each apartment/family should spend between 14,000 $\pm 3200 \mathrm{CHF}$ and 27,000 $\pm 6200 \mathrm{CHF}$ (approx. between 12,000 \pm 2760 and 23,500 \pm $5400 €)$ for the installation of the geothermal system, depending on location and on-site potential. The total costs were then divided by the installed heat capacity $(25 \mathrm{~kW})$ to calculate a specific capital cost $(\mathrm{CHF} / \mathrm{kW})$. An advantageous cost per installed $\mathrm{kW}$ of a GSHP system is estimated to be between 3000 and $3500 \mathrm{CHF} / \mathrm{kW}(2600-3000 € / \mathrm{kW})$. A potential user/stakeholder could also invest more money, 
approximately between 3500 and $4000 \mathrm{CHF} / \mathrm{kW}$ (3000-3500 €/kW), but the investment would become less and less profitable with longer payback periods and loss of attractiveness.

Table 9. Economic parameters for the costs estimate: the drilling technique used for consolidated sedimentary rocks and unconsolidated material was direct flush mud rotary while the drilling technique used within hard rock is down the hole-hammer.

\begin{tabular}{|c|c|c|c|}
\hline Parameters & Hard Rock & $\begin{array}{c}\text { Consolidated } \\
\text { Sedimentary Rock }\end{array}$ & $\begin{array}{c}\text { Unconsolidated } \\
\text { Material }\end{array}$ \\
\hline Drillability (CHF/m) & 91.2 & 105.2 & 101.5 \\
\hline Heat Pump: cost per $\mathrm{kW}(\mathrm{CHF} / \mathrm{kW})$ * & & 1000 & \\
\hline Probe cost $(\mathrm{CHF} / \mathrm{m}) * *$ & & 15.7 & \\
\hline Grouting $(\mathrm{CHF} / \mathrm{m})^{* * *}$ & & 6.6 & \\
\hline
\end{tabular}

\subsubsection{MATLAB/Octave Tool for Payback Period Estimate}

A crucial topic was to assess the potential economic attractiveness of closed-loop shallow geothermal energy systems against the current heating systems in Cantone Ticino, which are mainly fossil ones (heating oil and natural gas, almost completely methane). The challenge was to spatialize this information, putting it on map. Global cost of the geothermal system were evaluated by mainly considering drilling depth and heat pump cost, plus the evaluation of maintenance and ancillary costs. The geothermal costs were compared with costs for fossil heating systems through the estimation of cumulative cash flows (savings and expenses) through an experimental MATLAB/Octave [33,34] tool that could estimate a series of economic/environmental indicators. The economic indicators are the payback period (the time after which the investment starts being profitable), the Net Present Value (NPV) of the investment, which is an economic index used to preliminarily evaluate the profitability of an investment before actually doing it, determining the current value of all future cash flows generated by a project after accounting for the initial capital investment. The tool also calculates the amount of saved $\mathrm{CO}_{2}$ emissions against referential oil and natural gas systems. This tool was initially developed for the purpose of mapping procedure, but it is a stand-alone application that can be used by any type of user which would like to have a preliminary economic feasibility of its geothermal project against one relying on fossil fuels. The complete description of the tool is reported in [Supplementary Material, Economic tool]. The user provides the tool with a series of information concerning a closed-loop geothermal system and concerning the fossil fuel system (heating oil or natural gas) that he wants to use as comparison. The tool calculates the costs for each system and the savings between a geothermal system and the chosen fossil fuel one. The tool also returns a payback period: by performing a series of simulations a linear relationship between BHE length and payback period for both heating oil and natural gas was found, considering a period of 25 years for the calculation of the cash flow.

The empirical relations are:

Payback period heating oil (years) without economic subsidies $=(0.0274 *$ required BHE length $)-4.2941$

Payback period natural gas $($ years $)=(0.0273 *$ required BHE length $)-3.1912$

Having a BHE length map and this relations allowed building experimental payback period maps, which are reported in Figure 7a for heating oil and in Figure $7 \mathrm{~b}$ for natural gas. 

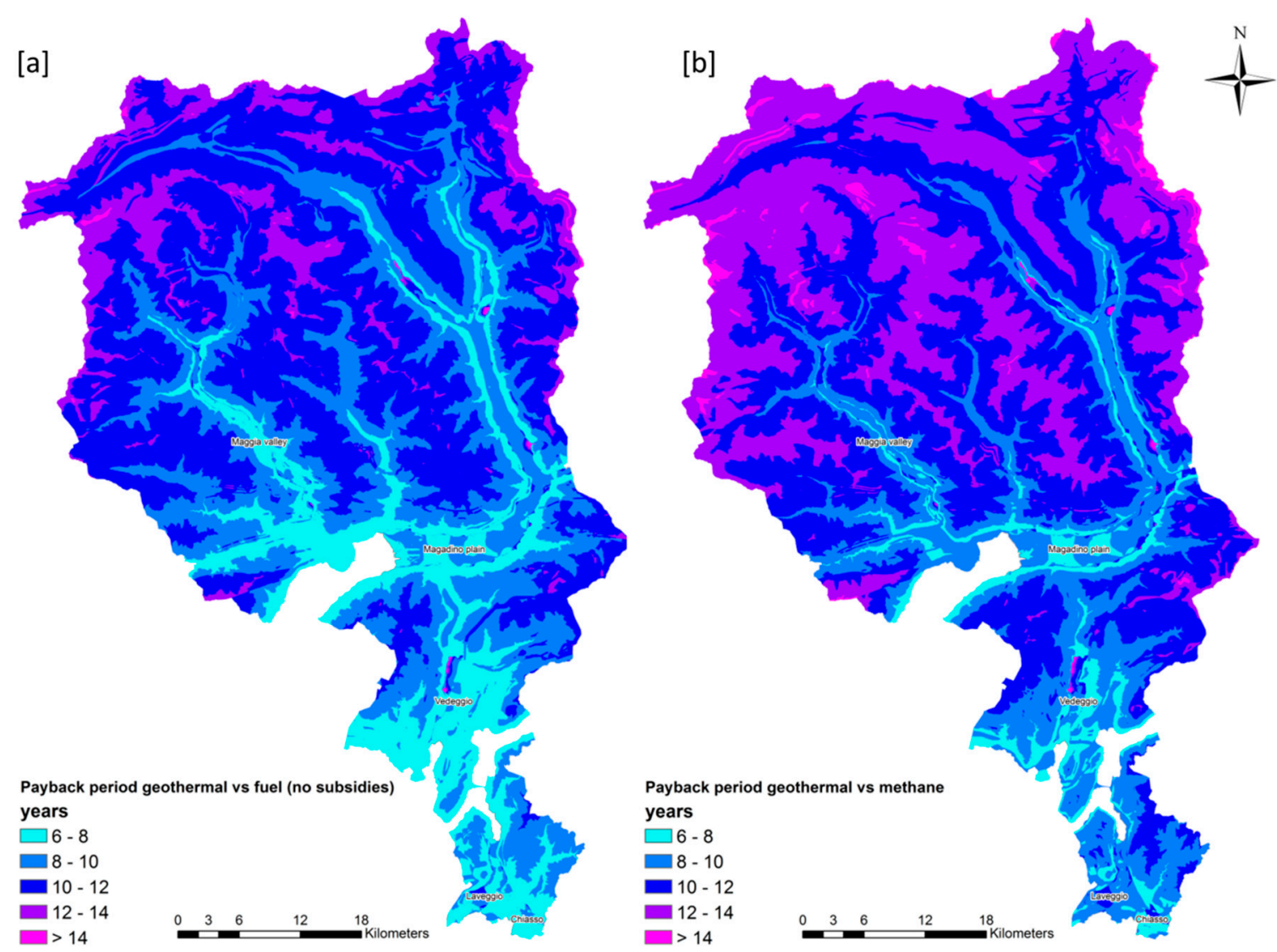

Figure 7. Maps of estimated payback period resulting from a geothermal vs heating oil analysis without considering economic subsidies (a) and geothermal vs natural gas (b).

The maps show that the payback period time for the considered referential geothermal system mainly ranges from 7 to 15 years, depending on thermal characteristics of the underground and its temperature. Payback periods $\geq 14$ years are only observed at elevations $>2000 \mathrm{~m}$, where the very low population density renders this assessment largely irrelevant, or in alluvial fans.

As previously said, aquifers host a greater potential for the installation of GSHP systems, mainly due to their presence at lower elevations and due to their larger thermal conductivities, caused by low groundwater depth (except for alluvial fans). On average the most promising place to install closed systems would be Chiasso aquifer, which requires on average approximately 7 years and 6 months to payback the investment when replacing an old heating oil system, while the less attractive aquifer is Laveggio requiring approximately 8 years and 6 months to payback the investment. The presence of Cantonal subsidies for replacing the oil system with a new geothermal one would cut down the payback periods of approximately one year.

The payback period estimate for a natural gas system (Figure 7b) states that it will take more time to return from the initial investment, (usually one year more, at least), since a natural gas system has much lower installation costs and similar operating costs than a heating oil one. The mapped values of payback periods must be seen considering an average error of $\pm 23 \%$ within the calculated $\mathrm{m} / \mathrm{kW}$ maps, but the produced maps still can highlight regions with longer or shorter payback periods.

The last created map was related to the profitability of the investment calculated from NPV. This relation was estimated by running several simulations using the economic tool for both oil and natural gas systems, considering an economic analysis of 25 years and a discount rate of $3 \%$ (the return that could be earned per unit of time on an investment with similar risk). Results showed that NPV turned negative for both comparisons when the required BHE length depth was $>500 \mathrm{~m}$. Figure 8 reports this information by classifying the study area into "profitable" and "unprofitable" depending on 
required BHE respectively lower or higher than $500 \mathrm{~m}$. When NPV is $>0$ the investment is profitable (it adds monetary value to the capital), otherwise it is unprofitable (does not add monetary value, the user should invest in some other projects). As expected, the map states that the investment in a new geothermal system compared to oil/methane system would be profitable in all valleys and aquifers and even at elevations of approximately $600 \mathrm{~m}$ a.s.l.

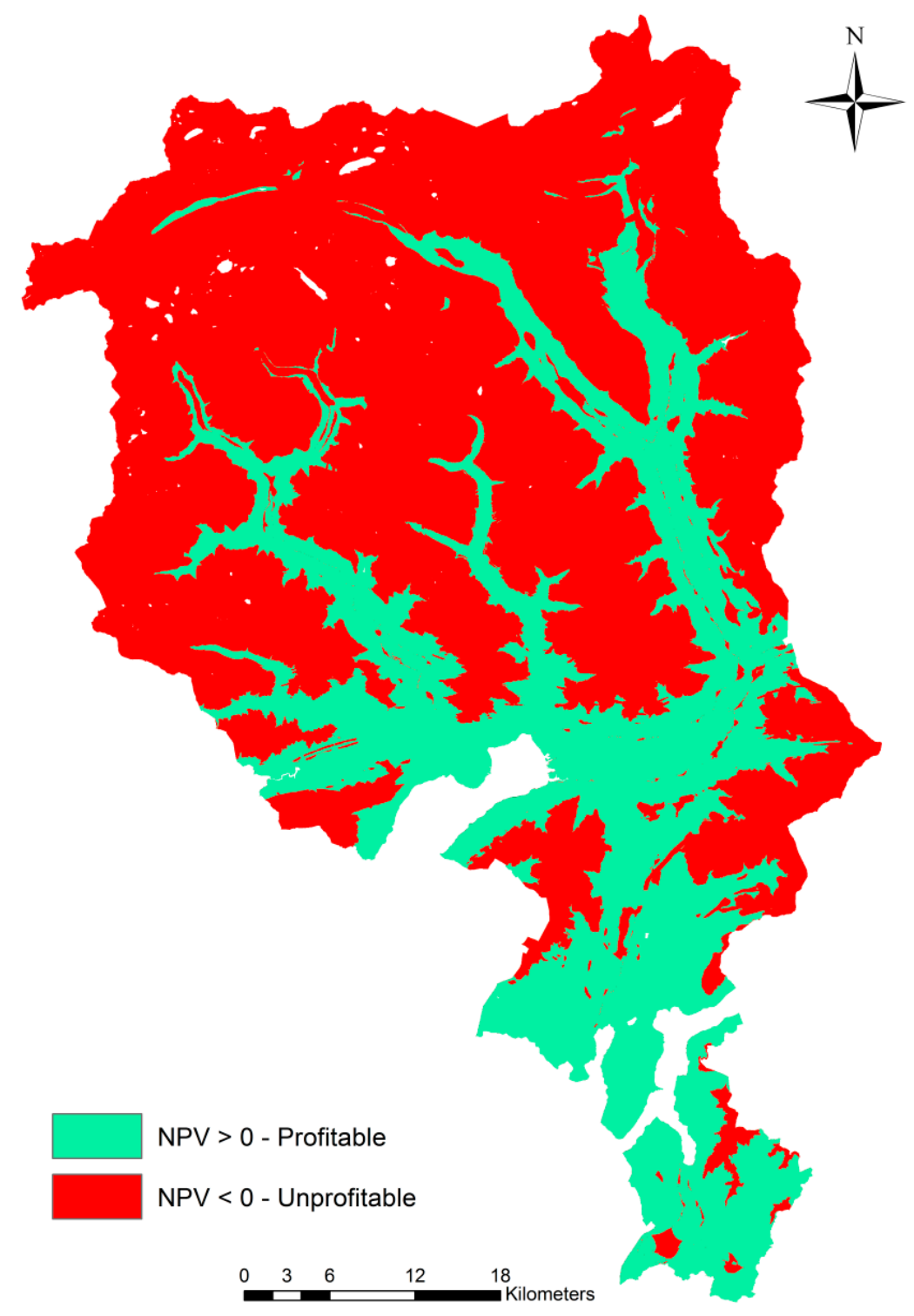

Figure 8. Map of profitability of the investment calculated for an economic analysis of 25 years. The areas where the investment would be profitable considering a discount rate of $3 \%$ (the return that could be earned per unit of time on an investment with similar risk) are reported in green. Red portion are zones where the investment in a closed-loop system would not be profitable, considering the NPV.

\section{3. $\mathrm{CO}_{2}$ Savings}

Swiss electrical energy is a type of low emission electric energy, because it is basically produced without fossil energetic vectors [35]. At the other hand the consumed electricity by the users has higher $\mathrm{CO}_{2}$ emissions, since the amount of $\mathrm{CO}_{2}$ emissions from the imported energy also have to be considered. Values of $t / \mathrm{CO}_{2}$ emissions per year contained in [35] were considered as referential and used in the estimation of total carbon dioxide emissions. 
The economic tool contains a part devoted to the calculation of the $\mathrm{CO}_{2}$ emissions given different type of energy vector. It estimates the potential savings in $\mathrm{CO}_{2}$ emission by the adoption of a closedloop geothermal system instead of heating oil or natural gas one. This is explained more in detail in [Supplementary Material, Economic tool]. Comparing the geothermal solution against fossil fuel systems and considering a COP of 4 (used in all EED simulations), the amount of saved $\mathrm{CO}_{2}$ emissions would be $6.8 \mathrm{tCO}_{2} /$ year for heating oil and $4 \mathrm{tCO}_{2} /$ year for natural gas. Considering a COP from 3 (worst case scenario) to 5 (best scenario) the emission savings would range from 6.3 to $7.1 \mathrm{tCO}_{2} /$ year for heating oil and from 3.5 to $4.3 \mathrm{tCO}_{2}$ /year for natural gas. The calculation of the savings of $\mathrm{CO}_{2}$ emissions is conceptually useful only if the geothermal system is chosen as an alternative/replacement to current heating systems. New systems do not provide any emission reduction and the geothermal systems that replace fossil fuel ones must also operate with electricity coming from low to zero $\mathrm{CO}_{2}$ emissions, as happens for Switzerland.

\subsection{Comparison of Produced Techno-Economic Maps with Available Regulation Maps}

A comparison between $\mathrm{m} / \mathrm{kW}$ map and the map related to closed-loop systems regulation is reported in Figure 9. The figure shows four different locations that were chosen within Cantone Ticino: all images compare $\mathrm{Au}$ areas where new closed-loop systems are allowed to be installed (bordered in blue) with the estimated potential in form of $\mathrm{m} / \mathrm{kW}$ map. In the second and fourth frame (upper right and lower right of Figure 9), two zones of the middle and southern part of Cantone Ticino are reported. The upper part of Vedeggio aquifer hosts a very low geothermal potential, mainly due to higher groundwater depth given the presence of many alluvial fans. The geothermal potential is observed to be very low, with consequent higher installation costs and operating costs due to deeper drilling and lower geo-exchange. The peculiarity of Au conflict zones is also that they are mainly located within alluvial fans or zones with high groundwater depth, with a consequently lower geothermal potential. The crucial aspect is that the areas where the installation of vertical geothermal probes is allowed often show a lower techno-economic potential. This means that the majority of BHEs are located in areas of low potential. At the other hand, results show that zones with higher techno-economic potential are interested by the occurrence of groundwater protection zones, where the installation of closed-loop systems is not allowed. Considering these results, it is clearly observable how the actual allocation of thermal resources reflects on the performances and costs of the systems. Given all the uncertainties that are intrinsic to a regional mapping as the proposed one, the allocation seems to be unoptimized, clearly raising regulation improvements.

Thermal interference and thermal resource management will be some of the most important topics to face in the next years: this could be assessed with more empirically verified maps. 

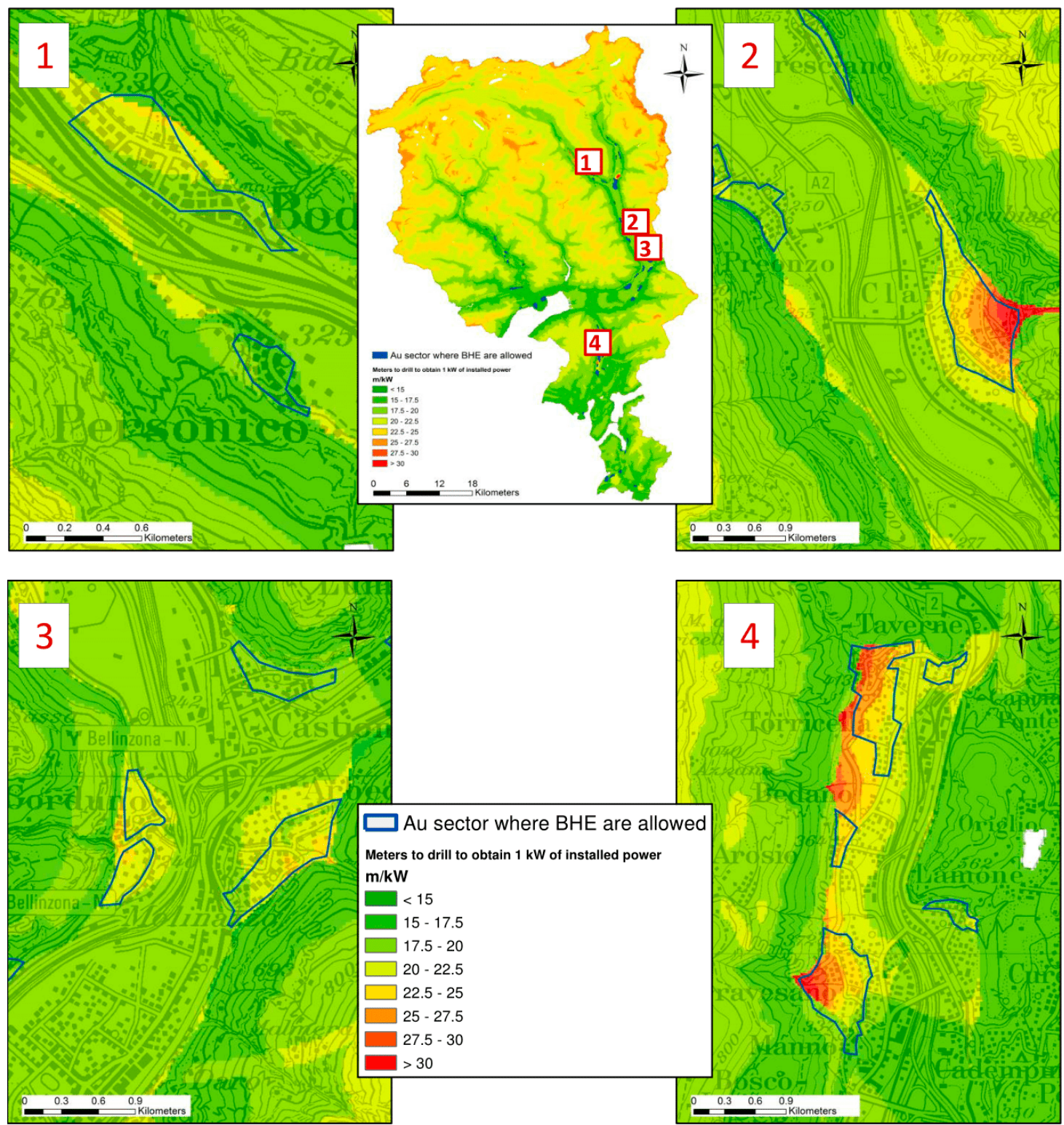

Figure 9. Comparison in some test areas between shallow geothermal potential expressed as $\mathrm{m} / \mathrm{kW}$ and areas where the installation of new BHE is allowed.

\section{Discussion}

Results showed that the referential building/GSHP system would require a BHE length between 400 and $700 \mathrm{~m}$ or, if expressed as an index, between 16 and $28 \mathrm{~m}$ for every $\mathrm{kW}$ of installed heating capacity $(\mathrm{m} / \mathrm{kW})$. Lower values of this index (and therefore a higher potential) are found within major valleys: this happens because the mean ground temperature is higher during the year and due to the shallower depth of the groundwater table, resulting in higher values of sediments thermal conductivity. $\mathrm{m} / \mathrm{kW}$ map was compared against 51 real geothermal systems and the average error was quantified in $23 \%$ or $\pm 6 \mathrm{~m} / \mathrm{kW}$. Further studies could focus on more detailed hydrogeological and thermal characterization of the subsurface using stored well logs and the detailed assessment of bedrock depth for each aquifer.

A spatial economic estimate of system costs was performed using documented prices and installation costs: it shows that this type of referential system could cost approximately between 80,000 CHF and 110,000 CHF (70,000 and 96,000€), with an estimated specific capital cost index between 3000 and $4500 \mathrm{CHF}$ (2600 and 3900€) per installed kW (CHF/kW). 
The estimated payback period for heating oil and natural gas systems ranges from approximately 7 to 15 years, depending on ground characteristics and air temperature. Regardless the intrinsic incertitude of the mapping process, natural gas systems require more time to be paid back compared to a heating oil system, because their capital cost is much lower than a heating oil system.

Sectors where new GSHP systems are allowed are often the locations where a lower geothermal potential is observed. This results in a non-optimized management of the geothermal resource that can lead to costs increase, efficiency decrease and potential loss of attractiveness of this renewable energy.

Moreover, in the next years, a strong interference issue between adjacent systems will probably occur, since closed-loop systems are only allowed in small portions of territory and a stable amount of new requests is observed. In light of these discoveries, a review of the current Cantone Ticino regulations regarding shallow geothermal energy and a more optimized allocation of the thermal resource should be strongly advised. Below some potential solutions (which do not consider the techno-economic-political feasibility):

- Widening of allowable areas: would promote the installation in new areas, but this would result in an increase of new requests, posing a serious threat to groundwater quality (from a chemical and thermal standpoint);

- Creation of large shallow geothermal systems that could do thermal storage plus district-heating: by creating new shallow geothermal installations in areas with high geo-exchange potential and by delivering the produced heat to areas having lower potential could optimize the management of the resource, since less geothermal systems in low potential areas would be needed. This solution could imply the use of Borehole Thermal Energy Storage systems, constituted of a large number of geothermal probes with short mutual spacing, which is beneficial in order to avoid leakage of heat/"cold" outside the borehole array [36].

Given the complexity of the input parameters and of the procedure, these mapping results are a good starting point for further analysis and characterization of the subsurface, in order to obtain more accurate maps. This could be done in the future through a systematic collection and publication by regulatory agencies of subsurface materials properties, through the development of an accessible database. In this way, map products would enhance regulatory efforts over time, as well as assist entities involved in the design and economic analyses of GSHP systems.

Supplementary Materials: The following are available online at http:/ / www.mdpi.com/1996-1073/12/2/279/s1, Figure S1: MAAT map of Cantone Ticino with chosen air temperature MeteoSwiss stations, Table S1: Measured thermal conductivity from TRT executed within Cantone Ticino, Figure S2: Reliability of litho-textural characterization of the subsurface, Table S2: 3D regression coefficients and fit for the identification of the BHE length regression, Figure S3: 3D regression between thermal conductivity (x1), Ground Surface Temperature (x2) and estimated BHE length (y), Table S3: Summary of all the 128 EED simulations performed to identify the polynomial regression between $\lambda$, GST, BHE length.

Author Contributions: R.P. wrote the paper, performed GIS calculations and mapping, plus EED simulations. R.P., S.P. and A.G. conceived the paper and the method used to create maps of shallow geothermal potential. S.P. and A.G. reviewed the paper and provided suggestions for its improvement. Sebastian Pera and Antonio Galgaro provided funding for the execution of the work and for its publication.

Funding: The work is related to Cheap-GSHPs project, which has received funding from the European Union's Horizon 2020 research and innovation programme under grant agreement No. 657982. The project aims at reducing the installation costs while improving the efficiency of closed-loop GSHP systems through the development of new technologies. SUPSI was involved in the realization of multi-parameter geothermal maps regarding the closed-loop shallow geothermal potential, therefore a methodology had to be found: the design and testing of the methodology was performed hereafter on Cantone Ticino. The work performed by SUPSI within Cheap-GSHPs was funded by the Swiss State Secretariat for Education, Research and Innovation (SERI) under contract No. 15.0176.

Acknowledgments: The authors would like to thank Michele Fre of Luzi Bohr-Drilling AG for the estimate of drilling costs for different lithologies, and Marco Belliardi from SUPSI for the support in doing EED simulations. The authors thank Galletti (Belgium) for providing them with some referential costs of their heat pumps and REHAU (Germany) for providing referential costs of grouting material. The authors would also like to thank the two anonymous reviewers that improved the paper through their suggestions and comments; moreover the authors thank the academic editor for its hints and insights. 
Conflicts of Interest: The authors declare no conflict of interest.

\begin{tabular}{ll}
\multicolumn{2}{l}{ Abbreviations and Symbols } \\
SUPSI & Scuola Universitaria Professionale della Svizzera Italiana \\
GSHP & Ground Source Heat Pumps \\
COP/EER & Coefficient of Performance/Energy Efficiency Ratio \\
MAAT/GST & Mean Annual Air Temperature/Ground Surface Temperature \\
MAE & Mean Absolute Error \\
RMSE & Root-Mean-Square Error \\
$k$ & Hydraulic conductivity \\
$\lambda$ & Thermal conductivity \\
TRT & Thermal Response Test \\
BHE & Borehole Heat Exchanger \\
EED & Earth Energy Designer \\
DHW & Domestic Hot Water \\
SPF & Seasonal Performance Factor \\
CHF & Swiss franc \\
NPV & Net Present Value
\end{tabular}

\section{References}

1. Lund, J.W.; Boyd, T.L. Direct utilization of geothermal energy 2015 worldwide review. Geothermics 2016, 60, 66-93. [CrossRef]

2. Swiss Federal Office of Energy SFOE. Available online: http://www.bfe.admin.ch/index.html?lang=en (accessed on 10 January 2019).

3. MINERGIE ${ }^{\circledR}$. Available online: https://www.minergie.ch/fr/certifier/minergie/?l (accessed on 10 January 2019).

4. Perego, R.; Guandalini, R.; Fumagalli, L.; Aghib, F.S.; de Biase, L.; Bonomi, T. Sustainability evaluation of a medium scale GSHP system in a layered alluvial setting using 3D modeling suite. Geothermics 2016, 59, 14-26. [CrossRef]

5. Consiglio di Stato Della Repubblica e Cantone Ticino, Regolamento Sull'utilizzazione Dell'energia (RUEn). 2008. (In Italian)Available online: https:/ / www3.ti.ch/CAN/RLeggi/public/index.php/raccolta-leggi/ legge/vid/09_36 (accessed on 10 January 2019).

6. Overview on Cantone Ticino's Energy, Cantonal Office of Statistics, February 2018. Available online: https:/ / www3.ti.ch/DFE/DR/USTAT/allegati/prodima/4308_energia.pdf (accessed on 10 January 2019).

7. Environment Division, Office of water Protection and Water Supply, State Council Proceedings 2016-Statistical Annex (Public Report). Available online: https://m4.ti.ch/fileadmin/CAN/TEMI/RENDICONTOCDS/ 2016/RENDICONTO/Allegato_statistico_2016_documento_completo.pdf (accessed on 10 January 2019).

8. GESPOS. Available online: https://geoservice.ist.supsi.ch/gespos/ (accessed on 10 January 2019).

9. Swiss Waters Protection Ordinance (WPO). 2010. Available online: https://www.admin.ch/opc/en/ classified-compilation/19983281/index.html (accessed on 10 January 2019).

10. Swiss Federal Office for the Environment FOEN, Exploitation de la Chaleur Tirée du Sol et du Sous-Sol. 2009. Available online: https:/ / www.bafu.admin.ch/bafu/fr/home/themes/eaux/publications/publicationseaux/exploitation-chaleur-tiree-sol-sous-sol.html (accessed on 10 January 2019).

11. Thüring, M. Regolamentazione Dello Sfruttamento Dell'energia Geotermica nel Canton Ticino, Sezione per la Protezione Dell'aria, Dell'acqua e del Suolo, Canton Ticino. 2006; (internal report).

12. Lopez, A.; Roberts, B.; Heimiller, D.; Blair, N.; Porro, G. US Renewable Energy Technical Potentials: A GIS-Based Analysis; United States National Renewable Energy Laboratory (NREL): Golden, CO, USA, 2012.

13. Schiel, K.; Baume, O.; Caruso, G.; Leopold, U. GIS-based modelling of shallow geothermal energy potential for $\mathrm{CO}_{2}$ emission mitigation in urban areas. Renew. Energy 2016, 86, 1023-1036. [CrossRef]

14. García-Gil, A.; Vázquez-Suñe, E.; Alcaraz, M.M.; Juan, A.S.; Sánchez-Navarro, J.Á.; Montlleó, M.; Rodríguez, G.; Lao, J. GIS-supported mapping of low-temperature geothermal potential taking groundwater flow into account. Renew. Energy 2015, 77, 268-278. [CrossRef] 
15. Bertermann, D.; Klug, H.; Morper-Busch, L. A pan-European planning basis for estimating the very shallow geothermal energy potentials. Renew. Energy 2015, 75, 335-347. [CrossRef]

16. Gemelli, A.; Mancini, A.; Longhi, S. GIS-based energy-economic model of low temperature geothermal resources: A case study in the Italian Marche region. Renew. Energy 2011, 36, 2474-2483. [CrossRef]

17. Casasso, A.; Sethi, R. Assessment and mapping of the shallow geothermal potential in the province of Cuneo (Piedmont, NW Italy). Renew. Energy 2017, 102, 306-315. [CrossRef]

18. Arola, T.; Eskola, L.; Hellen, J.; Korkka-Niemi, K. Mapping the low enthalpy geothermal potential of shallow Quaternary aquifers in Finland. Geotherm. Energy 2014, 2, 9. [CrossRef]

19. Viesi, D.; Galgaro, A.; Visintainer, P.; Crema, L. GIS-supported evaluation and mapping of the geo-exchange potential for vertical closed-loop systems in an Alpine valley, the case study of Adige Valley (Italy). Geothermics 2018, 71, 70-87. [CrossRef]

20. Galgaro, A.; di Sipio, E.; Teza, G.; Destro, E.; de Carli, M.; Chiesa, S.; Zarrella, A.; Emmi, G.; Manzella, A. Empirical modeling of maps of geo-exchange potential for shallow geothermal energy at regional scale. Geothermics 2015, 57, 173-184. [CrossRef]

21. Hellström, G.; Sanner, B. Earth Energy Designer 3.2. Manual. Available online: https://www. buildingphysics.com/manuals/EED3.pdf (accessed on 10 January 2019).

22. SIA Schweizerischer Ingenieur- und Architekten-Verein. Sondes Géothermiques, 1st ed.; SIA: Zurich, Switzerland, 2010.

23. MeteoSwiss. Available online: https:/ / www.meteoswiss.admin.ch/ (accessed on 10 January 2019).

24. Signorelli, S.; Kohl, T. Regional ground surface temperature mapping from meteorological data. Glob. Planet. Chang. 2004, 40, 267-284. [CrossRef]

25. IDAWEB. Available online: https://gate.meteoswiss.ch/idaweb/login.do (accessed on 10 January 2019).

26. Federal Office of Topography Swisstopo. Available online: https://www.swisstopo.admin.ch/ (accessed on 10 January 2019).

27. Linda, S. Interplay between Opposite Vergence Thrusts along the Southern Alps Margin in Canton Ticino (Switzerland): Geometry and Kinematics in Support of the Characterization of Geothermal Potential. Ph.D. Thesis, Pavia, Italy, 2015.

28. Luo, J.; Tuo, J.; Huang, W.; Zhu, Y.; Jiao, Y.; Xiang, W.; Rohn, J. Influence of groundwater levels on effective thermal conductivity of the ground and heat transfer rate of borehole heat exchangers. Appl. Therm. Eng. 2018, 128, 508-516. [CrossRef]

29. Freeze, R.A.; Cherry, J.A. Groundwater; Prentice-Hall: Englewood, NJ, USA, 1979.

30. Fetter, C.W. Applied Hydrogeology, 4th ed.; Prentice Hall: Upper Saddle River, NJ, USA, 2001.

31. Federal Office of Statistics, Statistics of Buildings and Residential Buildings, Neuchâtel. Available online: http:/ / www3.ti.ch/DFE/DR/USTAT/allegati/prodima/4509_costruzioni_e_abitazioni.pdf (accessed on 10 January 2019).

32. Republic and Cantone Ticino-Cantonal Energetic Plan. Available online: http://www4.ti.ch/generale/ piano-energetico-cantonale/tema/tema/ (accessed on 10 January 2019).

33. MATLAB. Available online: https:/ / www.mathworks.com/products/matlab.html (accessed on 10 January 2019).

34. GNU OCTAVE. Available online: https://www.gnu.org/software/octave/ (accessed on 10 January 2019).

35. Swiss Federal Office for the Environment FOEN. Compilation of the $\mathrm{CO}_{2}$ Emission Factors and Energy Content of the Various Energy Sources that Are Used in the Greenhouse Gas Inventory; Swiss Federal Office for the Environment FOEN: Ittigen, Switzerland, 2016.

36. Banks, D. An Introduction to Thermogeology: Ground Source Heating and Cooling; John Wiley \& Sons: Hoboken, NJ, USA, 2012.

(C) 2019 by the authors. Licensee MDPI, Basel, Switzerland. This article is an open access article distributed under the terms and conditions of the Creative Commons Attribution (CC BY) license (http:/ / creativecommons.org/licenses/by/4.0/). 